Board of Governors of the Federal Reserve System

International Finance Discussion Papers

Number 1302

September 2020

\title{
Intermediary Asset Pricing during the National Banking Era
}

Colin R. Weiss

Please cite this paper as:

Weiss, Colin R. (2020). "Intermediary Asset Pricing during the National Banking Era," International Finance Discussion Papers 1302. Washington: Board of Governors of the Federal Reserve System, https://doi.org/10.17016/IFDP.2020.1302.

NOTE: International Finance Discussion Papers (IFDPs) are preliminary materials circulated to stimulate discussion and critical comment. The analysis and conclusions set forth are those of the authors and do not indicate concurrence by other members of the research staff or the Board of Governors. References in publications to the International Finance Discussion Papers Series (other than acknowledgement) should be cleared with the author(s) to protect the tentative character of these papers. Recent IFDPs are available on the Web at www.federalreserve.gov/pubs/ifdp/. This paper can be downloaded without charge from the Social Science Research Network electronic library at www.ssrn.com. 


\title{
Intermediary Asset Pricing during the National Banking
}

\section{Era}

\author{
Colin Weiss*
}

\begin{abstract}
Financial intermediary balance sheets matter for asset returns even when these intermediaries do not directly participate in the relevant asset markets. During the National Banking Era, liquidity conditions for the New York Clearinghouse (NYCH) banks forecast excess returns for stocks, bonds, and currencies. The NYCH banks had little to no direct participation in these markets; their main link to these markets was through securities financing. Liquidity conditions affect asset prices through the credit growth of the NYCH banks, which shapes marginal investors' discount rates. I use institutional features of this era to provide evidence in favor of this mechanism.
\end{abstract}

Keywords: Liquidity management, Margin loans, Intermediary asset pricing, National banks

JEL CODES: G12, G21, E51, N21

*Division of International Finance, Board of Governors of the Federal Reserve System, Washington D.C. 20551 USA. E-mail: colin.r.weiss@frb.gov. I thank Mark Carlson, Adrien d'Avernas, Laurie Demarco, Sai Ma (discussant), John Rogers, and participants in workshops at the Federal Reserve Board of Governors and NYU Stern for helpful comments. Lucille Conrad and Julio Monge offered outstanding research assistance. The views expressed in this paper are solely my own and do not reflect the views of the Board of Governors of the Federal Reserve or anyone else associated with the Federal Reserve system. All errors are my own. 


\section{Introduction}

Financial intermediary balance sheets have been shown to correlate with aggregate measures of risk premia in the economy (He and Krishnamurthy, 2018). The intermediary asset pricing literature argues it is due to frictions faced by the intermediaries that are the marginal investors in a variety of assets, but proving this argument is difficult. First, intermediary balance sheet changes may reflect other factors that affect asset prices. Second, the intermediaries typically studied in the empirical literature-dealer banks-perform a number of roles in financial markets, including buying and selling securities for their own account, buying and selling for customers, and lending on security collateral through repurchase agreements (Duffie, 2010) $!^{1}$

I study the relationship between bank balance sheets and asset prices in an historical setting with two key features useful for understanding why intermediary health is reflected in asset prices. First, the set of banks I study were only connected to assets through their supply of margin loans. Second, lending for these banks was sometimes constrained by an occasionally-binding regulatory constraint. During the National Banking Era in the U.S. (1863-1913), commercial banks with a national charter (national banks) could not directly purchase equities, owned a limited amount of corporate bonds (less than 5 percent of bonds outstanding in 1912), and did not trade foreign exchange until after 1900. However, the New York City national banks were still connected with asset markets, as a large portion of their loans were on stock and bond collateral in order to finance the trading activities of brokers and other investors. Additionally, it was widely recognized at the time that these banks' lending capacity was limited in periods when the reserve requirement (equal to 25 percent of deposits) was binding or near binding.

I find that the balance sheet conditions of the New York City banks still affect asset prices, even though these banks have limited participation in asset markets. Specifically, I

\footnotetext{
${ }^{1}$ In fact, during the last several years, the largest single asset category for securities broker-dealers in the financial accounts of the U.S. is reverse repurchase agreements.
} 
hand-collect key balance sheet items for the New York City Clearinghouse (NYCH) Banks- of which the New York City national banks were the primary members-at a monthly frequency between 1868 and 1913. Focusing on predictors of NYCH loan growth, I first show that higher growth in cash reserves and lower growth in the loan-to-deposit ratio (both of which predict higher loan growth over the next year) for the NYCH banks predict higher excess returns for stocks, corporate bonds, and lower excess returns for the dollar relative to other currencies over several quarters with high in-sample and out-of-sample $R^{2} \mathrm{I}^{2}$ The economic significance is also sizable: a standard deviation increase in reserve growth forecasts an annualized excess return for stocks that is five percentage points higher two quarters ahead ${ }^{3}$

Next, I argue that frictions limiting the NYCH banks' ability to supply margin loans are responsible for the predictability of returns. I present several pieces of evidence to support this claim. First, NYCH bank balance sheets do not forecast annual dividend growth, suggesting they affect investors' discount rates rather than securities' cash flows. I then use the occasionally-binding nature of the reserve requirement to separate supply shocks for margin loans from demand shocks originating from changes in investors' risk appetite. I show that the predictability from NYCH bank balance sheets only holds in periods where the banks are closer to the minimum reserve-deposit ratio. Further, the forecasting relationship holds in low-reserve states even controlling for output growth over the forecast horizon, suggesting that low reserves do not simply coincide with changes in future consumption growth. Further, NYCH bank balance sheets forecast money market rates in the U.K., where aggregate money market credit did not face the same supply constraint and overnight margin loans were less important for securities purchases as compared to the U.S., but NYCH bank balance sheets do not forecast excess returns for British equities over the same horizon. Finally, I present evidence that predictability is specifically due to margin loan provision by

\footnotetext{
${ }^{2}$ I run quarterly forecasting regressions despite some monthly data to incorporate a larger set of macroeconomic predictors. The predictive power also holds at the monthly horizon without the full set of macroeconomic controls.

${ }^{3}$ Relatedly, Jordà et al. (2017) find similar bank balance sheet variables-specifically the loan-to-deposit ratio-help predict the timing of financial crises.
} 
the NYCH banks. Balance sheets for the NYCH banks that were less important in supplying margin loans do not forecast excess returns.

These findings have stark implications for the intermediary asset pricing literature. Previous empirical papers have studied intermediaries that directly participate in asset markets (examples include Adrian, Etula, Muir, 2014; Adrian, Moench, Shin, 2019; and He, Kelly, Manela, 2017) or relied on direct participation to test for the importance of intermediaries in asset pricing (Baron and Muir, 2020; Du, Hebert, Huber, 2019; Haddad and Muir, 2020). In contrast, I show that even intermediaries that do not trade a given set of assets still face constraints that matter for those assets' prices. The key detail is that these are the intermediaries that fund traders.

These results also complement recent work by Baron and Muir (2020), who find that commercial bank asset growth forecasts returns for a variety of asset classes in multiple countries over a long time span. Like their paper, I also find predictability at a relatively short horizon with loan growth coinciding with periods of compressed risk premia. Their predictability results are strongest when examining the balance sheets of intermediaries who were likely the marginal investors of a given security. In contrast, I use the institutional features of the National Banking era to show strong predictability for a set of banks that were not the marginal investors. Further, I document the specific importance of liquidity mismatches for understanding this predictability, while they do not take a stand on specific frictions driving their predictability results.

The importance of margin trading for asset prices has been studied in several theoretical papers (Brunnermeier and Pedersen, 2009; Gârleanu and Pedersen, 2011; Geanakoplos, 2010) $4^{4}$ Indeed, the role of margin constraints also motivates empirical intermediary asset pricing studies (Adrian, Etula, Muir, 2014). However, this literature typically abstracts from any constraint on those agents providing the margin loans. Two important exceptions are Piazzesi and Schneider (2018), who build a model where banks' liquidity management affects

\footnotetext{
${ }^{4}$ Consistent with these models, Kahraman and Tookes (2017) show that margin buying improves stock market liquidity, except in crises when trader deleveraging impairs market functioning.
} 
asset prices through margin traders' funding costs, and He, Nagel, Song (2020), who study how dealer banks' ability to provide repo financing to hedge funds affects U.S. government bond prices $5^{5}$ My results confirm that these constraints have important asset pricing effects. The historical setting of this paper, where the intermediaries providing securities financing were not also the marginal investors, offers a cleaner test of the argument that the balance sheet health of those providing funding affects risk pricing.

Finally, a large literature has used institutional features of the National Banking Era in the U.S. to study a broad range of questions such as how interbank networks transmit shocks across the banking system (Anderson, Paddrik, Wang, 2019; Calomiris and Carlson, 2017), the effects of liquidity regulations (Gorton, Laarits, Muir, 2020), and how the lack of a lender of last resort affects interest rate and stock price volatility (Bernstein, Hughson, Weidenmier, 2010). Here, I exploit the limited participation of the national banks in financial markets to test theories of intermediary asset pricing. Because I link bank balance sheets with asset prices, my paper resembles Chabot (2011) and Hanes and Rhode (2013). In contrast to these papers, I focus on return predictability and explicitly provide evidence for why NYCH bank balance sheet health forecasts risk premia.

I organize the rest of the paper as follows. Section 2 provides information on the NYCH banks, their role in money markets, and the national bank system. Section 3 describes the empirical strategy and the data before presenting the main results regarding predictability. Section 4 documents the evidence in favor of constraints on NYCH bank loan supply as the mechanism creating predictability. Section 5 reviews the results, policy implications, and directions for future research.

\footnotetext{
${ }^{5}$ The financial frictions present in Piazzesi and Schneider (2018) have been studied in related contexts by Bianchi and Bigio (2018), Bigio and Sannikov (2019), d'Avernas, Vandeweyer, Pariès (2020), and Drechsler, Savov, Schnabl (2018).
} 


\section{19th-Century Commercial Banks, the National Banking System, The Call Money Market}

It is useful to review the features of the 19th-century U.S. commercial banking system and the relation of these banks to asset markets in order to understand the choices made in the empirical analysis. I begin by reviewing bank-level balance sheet decisions before discussing broader institutional features of the national banking system in the U.S. This section draws heavily on James (1978). Other excellent sources for understanding the relationship between banks, the money markets, and stock exchanges are Myers (1931) and Griffiss (1925). Hanson et al. (2015) also offer a detailed description of 19th-century commercial bank activity in the U.S.

The balance sheet of a typical national bank would stand out particularly for its lack of diversification on the asset side. Banks tilted their asset portfolios heavily towards loans and discounts, and most loans were short-term commercial loans. Partially, this reflected regulations imposed by the National Bank Acts (NBA) of 1863 and 1864, as will be discussed below. But, to a large extent, this simply followed from the prevailing wisdom at the time. For instance, a prominent scholar noted in 1908 that "selling stocks and bonds, underwriting the purchase and sale of corporate issues...are not banking" (Cleveland, 1908). Indeed, even as bankers gradually recognized the benefit of holding a "secondary reserve" of bonds towards the end of the 19th century, bonds never topped 10 percent as a share of national bank assets prior to 1913. Similarly, foreign exchange trading was primarily done by private banks in New York City until around 1900, when national banks across the U.S. began creating foreign departments to trade foreign exchange (Myers, 1931). Equities were generally viewed as too risky an investment and were illegal to own directly in the case of the national banks. Furthermore, the NBA also outlawed real estate loans, though national banks in rural areas did not always abide by this restriction.

On the liabilities side, national banks had two key sources of funding, though one source grew dominant over the time period. First, national banks funded themselves through the 
issue of bank notes. The second and more important source of funding was demand deposits, which grew from five percent of GDP in 1864 to nearly 25 percent by 1912 (Jaremski and Rousseau, 2018) [6 Deposits could either come from individuals or from other banks. For the NYCH Banks, the latter category was especially important.

The practice of banks depositing funds in other banks emerged prior to the national bank system, but the NBA effectively institutionalized this system. Initially, rural banks found it convenient to hold deposits in banks in commercial and financial centers to help settle balances incurred as a result of international and inter-regional trade, creating a widespread correspondent banking network (Moen and Tallman, 2003). New York City, as the largest commercial and financial hub, attracted a large amount of these bankers' deposits. The NBA, through their reserve requirements, cemented the necessity of a correspondent banking network and created a pyramid structure of national bank reserve holdings. Rural and small town banks (classified as country banks by the NBA) had to hold 15 percent of their deposits as reserves, but three-fifths of these reserves could be deposits in reserve city or central reserve city national banks. Reserve city banks (national banks in cities with populations greater than 50,000) had to hold reserves equal to 25 percent of deposits, but half could be held as deposits in central reserve city banks. Finally, national banks in the central reserve cities of New York, Chicago, and St. Louis had to hold 25 percent of their deposits as reserves in the form of gold or legal tender. As a result, a large portion of national bank reserves ended up as deposits in New York City national banks.

Aside from regulations limiting the types of assets national banks could hold or specifying the minimum level of reserves, the other important regulation on national banks set a minimum capital requirement. The minimum required level of paid-in capital varied by city size and was set in absolute terms. In other words, capital requirements did not restrict leverage, either in absolute or risk-adjusted terms.7 Instead, liquidity management

\footnotetext{
${ }^{6}$ These demand depoaits were uninsured, as federal deposit insurance did not exist at the time.

${ }^{7}$ The notion of Value-at-Risk did not exist during the national banking era; it was an innovation in the latter half of the 20th century.
} 
considerations-- potentially through the reserve requirements-constrained national banks' loan issuance. According to a leading banking textbook at the time: "the necessity of maintaining a certain minimum reserve fixes a limit to the ability of the bank to increase its securities [loans and bonds]...If, then, the reserve were already as low prudence would allow, or were threatened by approaching heavy demands from depositors, no increase of securities could be made without serious risk" (Dunbar, 1891). I provide additional narrative evidence on liquidity conditions, loan expansion, and asset prices in the Appendix.

Given that banker deposits were especially prone to withdrawals on short notice, the NYCH banks needed a particularly liquid and safe set of investments ${ }^{8}$ The best option available was margin loans made to brokers and other stock and bond traders that could be called at any time (hence the name "call loans"). Since call loans were made on stock or bond collateral, they were viewed as relatively safe-and in normal times they were (Moen and Tallman, 2003). As a result, call loans were the single largest category of loans held by the NYCH banks: for the majority of the National Banking Era, call loans averaged around half of NYCH banks' loans (James, 1978). In turn, the NYCH banks were the dominant source of funds in the call loan market before 1900 (Moen and Tallman, 2003) $!^{9}$ Finally, call loans were the main source of liquidity for the stock exchanges in New York City, as margin loans available with fixed maturities proved to be far less popular 10

The absence of a central bank in the United States affected the New York money market in two important ways. First, both money demand and the money supply varied seasonally with the movement of crop exports. Demand for money peaked in the autumn as banks in the interior of the U.S. withdrew money from NYCH banks, producing a strain on

\footnotetext{
${ }^{8}$ This was especially true because interbank borrowing by central reserve city was generally small. According to James (1978): "Such borrowing would have been inconsistent with their position as banks of deposit for other banks." Even in times of financial strain, banks in central reserve city banks still tended to be net lenders of interbank funds (James, 1978).

${ }^{9}$ The emergence of a set of private investment banks in New York City known as "trust companies" with a level of resources similar to the NYCH banks in the late 1890s weakened NYCH bank control of the call loan market.

${ }^{10}$ Fohlin et al. (2016) show that interest rates on call loans affected stock market liquidity during the Panic of 1907.
} 
New York money markets especially because there was no central bank to meet this increased demand for currency (Goodhart, 1969). Second, without a central bank to rediscount money market instruments (as the Bank of England did, for example), the liquidity of call loans, time loans, and commercial paper (the three main money market instruments) was far less than their foreign equivalents (Coleman, 2012). As a result of these two facts, short-term interest rates in the U.S. were generally higher than in many major European countries, and these interest rate differentials varied with liquidity conditions in the U.S.

Liquidity conditions for the NYCH banks generally varied for three main reasons (Sprague, 1913). As noted in the previous paragraph, there was a large seasonal movement of money within the U.S. Money flowed out of the NYCH banks and liquidity tightened in the autumn (especially September and October) to facilitate the harvesting of the primary export crops. During the winter months, money returned to the NYCH banks and conditions in the New York money market eased. While these movements were predictable, understood at the time, and in some ways prepared for by the NYCH, and unexpectedly strong (or weak) harvest would tend to exaggerate these seasonal swings. In addition to these seasonal changes, liquidity conditions for the $\mathrm{NYCH}$ banks also varied with changes in the federal government surplus or deficit. This was a byproduct of the independent treasury system in place at the time, where the Treasury's vault cash was not kept in the banking system. Therefore, rising government deficits increased the cash holdings of the NYCH banks, while greater surpluses reduced the cash reserves for the NYCH banks. Finally, net imports of gold from abroad increased the reserves of the NYCH banks. The Appendix contains narrative evidence of how these factors affected the New York money market at specific times during the National Banking Era. 


\section{$3 \quad$ NYCH Balance Sheets \& Return Predictability}

I test whether NYCH bank balance sheets are relevant for asset prices by seeing whether some component of NYCH balance sheets forecasts excess returns across different asset classes. ${ }^{11}$ I focus on predictability that results from constraints on $\mathrm{NYCH}$ banks' loan growth, in line with other studies of intermediary asset pricing theories. The previous section suggests that the relevant constraint was the banks' liquidity condition as opposed to the net worth or risk-based debt constraints studied in modern settings ${ }^{12}$ I measure NYCH banks' liquidity conditions using two variables: year-over-year growth in cash reserves or year-over-year growth in the loan-to-deposit (LtD) ratio. I use year-over-year changes to deal with the seasonality of NYCH bank balance sheets. Both measures use month-end values taken from weekly balance sheet statements for the NYCH; see Table A1 in the Appendix for additional information on sources.

I now provide evidence that NYCH bank liquidity conditions affected future loan growth at the monthly frequency $[13$ Figure 1 shows that peaks in reserve growth and troughs in LtD ratio growth tend to occur just prior to peaks in NYCH bank loan growth, while peaks in LtD ratio growth and troughs in reserve growth often occur in the month before $\mathrm{NYCH}$ loan growth reached a trough. Formally, Granger causality tests, with p-values reported in Table 1, confirm these visual patterns. These p-values show that I can overwhelmingly reject the null hypothesis that cash reserve changes or LtD ratio changes provide no information

\footnotetext{
${ }^{11}$ Previous papers studying intermediary asset pricing through the lens of return predictability are Adrian, Etula, Shin (2015); Adrian, Moench, Shin (2019); Baron and Muir (2020); Correa and Demarco (2019); and Haddad and Muir (2020). Although they focus primarily on cross-sectional tests, He, Kelly, and Manela (2017) also show that their intermediary equity forecasts returns.

${ }^{12} \mathrm{He}$, Kelly, Manela (2017) argue that stable deposit funding is key for the relevance of net worth constraints. Without deposit insurance and somewhat frequent banking panics, it would seem the NYCH banks fail to meet this criteria.

${ }^{13}$ Banks outside of New York City could also invest directly in call loans. This could present a problem for the argument that NYCH loan growth mirrors growth in the volume of call loans. Suppose a country bank switches from holding its excess reserves as deposits in NYCH banks to directly investing them in call loans. Such a switch would reduce NYCH reserves and therefore their loans, but the volume of call loans would be relatively unaffected. However, the volume of call loans generally tracked the amount of bankers deposits in NYCH banks, suggesting reductions in NYCH call loans due to reserve losses were not offset by increases in call loans from out-of-town banks (James, 1978).
} 
about future values of loan growth regardless of the number of lags included (with the lags chosen varying by selection criteria). The p-values for Granger causality tests in the other direction (not shown, but available upon request) are either insignificant in the case of cash reserves or larger for LtD ratio changes. Table A2 in the Appendix shows that the liquidity measures also Granger cause call loan rates and year-over-year changes in call rates.

The main test of the paper thus examines whether NYCH bank liquidity conditions predict quarterly excess returns for stocks, high-grade corporate bonds, and currencies, while controlling for a host of other traditional predictors used in the finance literature (see Goyal and Welch (2008) for a discussion of these predictors). In line with the existing intermediary asset pricing literature, I focus on relatively near-term return predictability, since this is the period over which binding intermediary constraints are likely to matter for asset prices. I therefore run the following predictive regressions for the three asset classes mentioned above:

$$
R_{t+h}=\alpha+\beta \Delta \operatorname{Bank}_{t}+\gamma^{\prime} z_{t}+\varepsilon_{t+h}
$$

where $R_{t+h}$ is the cumulative excess return from quarter $t$ to quarter $t+h$ for $h \in[1,12]$ expressed at an annualized rate. Stock returns are calculated using quarter-end values of the Cowles Commission common stock price index, which was the precursor to the S\&P stock price index in the U.S. ${ }^{14}$ Bond returns use quarter-end values of the index of high-grade railroad bond prices based on the bonds used in Macaulay (1938). The risk-free rate used to calculate excess returns for stocks and bonds is the open market discount rate in London. ${ }^{15}$ The currency excess return index was hand-collected for this study and is the excess return on

\footnotetext{
${ }^{14}$ An alternative stock price index has been constructed by Goetzmann, Ibbotson, Peng (2001). The findings discussed below hold when using this alternative index to compute stock excess returns. See the Appendix for further discussion.

${ }^{15}$ There were no short-term U.S. government debt instruments at the time, and U.S. money market rates were not necessarily risk-free. Baron and Muir (2020) make a similar argument for using real returns instead of excess returns especially since the relevant intermediaries may also be the marginal investors in money markets. Because the NYCH banks were unlikely to be the marginal investors in the London discount market, I am less concerned about this argument, and so use excess returns for the main results. Figure A1 in the Appendix reports similar, albeit weaker, results using real stock and bond returns as the outcome variables in the predictive regressions. The weaker results are likely in part due to the volatility of inflation during this period.
} 
a short-term dollar investment relative to an equally-weighted portfolio of the four currencies that could be traded in the New York City markets: the British pound, the French franc, the German mark, and the Dutch guilder 16 Further details on the construction of this index and all other variables can be found in the Appendix ${ }^{17}$

The main predictor of interest is $\Delta B a n k_{t}$, which measures the year-over-year change in either NYCH banks' end-of-quarter cash reserves or end-of-quarter LtD ratio. The control variables, $z_{t}$, are other common return predictors studied in the literature for which data are available during the national banking era. The first predictor is the one-quarter excess return at time $t$, meant to capture the momentum factor in asset markets. The second predictor is year-over-year growth in real GNP to control for how broader macroeconomic developments affect risk premia. The last two predictors are common measures of the value of stocks relative to their cash flows, and likely reveal information about investors' discount rates: the dividend yield and the earnings-price ratio ${ }^{18}$ See Table A1 in the Appendix for data sources.

Figure 2 shows the effects of a standard deviation increase in either NYCH banks' LtD ratio growth or cash reserve growth on cumulative excess returns for stocks, bonds, or currencies, based on estimates of (1). Across all asset classes, NYCH bank balance sheets are a statistically significant predictor of excess returns for several quarters. The effects are strongest at relatively short horizons: peak effects occur between one and two quarters ahead, with estimates becoming weaker and insignificant as the forecast horizon increases. Furthermore, effects are in the expected direction for each asset class. For stocks and bonds, higher growth in the LtD ratio forecasts lower cumulative excess returns for all three asset classes, while higher growth in cash reserves forecasts higher excess returns.

\footnotetext{
${ }^{16}$ Foreign exchange markets were relatively undeveloped in the U.S. at this time. Most foreign exchange trading was done in London with conversions of foreign currencies to British pounds.

${ }^{17}$ Currency returns are constructed in this paper in the opposite direction relative to most existing studies (e.g. He, Kelly, Manela, 2017 or Baron and Muir, 2020). I focus on the excess return of a dollar investment because it makes the role of liquidity risk in the New York money market more apparent in the results.

${ }^{18}$ Another important predictor that is unavailable for a significant portion of the National Banking Era is the volatility of the stock market. Data for this measure begin in 1885 . The general conclusions hold when including lagged stock market volatility as an additional regressor.
} 
Both suggest that, when NYCH banks can (and do) extend more loans to speculators in the future, this pushes up stock and bond prices. I construct the confidence bands using Hodrick (1992) standard errors to deal with the autocorrelation in the dependent variable caused by the overlapping structure of cumulative returns 19 I additionally report significant results using non-overlapping samples for two-, three-, and four-quarter cumulative excess returns in Figure A2 of the Appendix.

For currencies, the signs on the NYCH bank balance sheet variables are opposite of what they are for stocks and bonds but still consistent with liquidity conditions being priced into assets. Recall that currency excess returns were calculated as the excess return of a short-term dollar instrument relative to a short-term foreign currency rate, net of dollar depreciation. Consider the example of an increase in LtD ratio growth. This is associated with strained funding liquidity and an increase in money market rates. The positive coefficient on LtD ratio growth at time $t$ suggests that the increase in the short-term dollar-foreign currency interest rate differential at time $t$ is not simply compensation for an increase in the expected dollar depreciation over the forecast horizon. Instead, it likely reflects the pricing of additional liquidity risk in the New York money market and the absence of this liquidity risk in foreign money markets. I review an alternative explanation based on unrealized dollar depreciation and the evidence against this explanation in the Appendix.

I next determine that the amount of information about future excess returns contained in NYCH bank balance sheets is sizable by examining the peak adjusted $R^{2}$ for each asset. I start with univariate regressions of excess returns for each asset class on the NYCH bank balance sheet variable; in all cases, the maximum adjusted $R^{2}$ occurs at the 3-quarter forecast horizon. For stocks, the adjusted $R^{2}$ at this horizon is 6.1 percent; for corporate bonds it is 12.4 percent; for dollar excess returns it is 7.6 percent. These numbers are similar in magnitude to the adjusted $R^{2}$ reported in Baron and Muir (2020). Additionally, adding the

\footnotetext{
${ }^{19}$ I further check for bias in the coefficients and standard errors due to small sample size and persistent regressors using the Campbell and Yogo (2006) tests. I find that the relevant statistics for the Campbell and Yogo (2006) tests are well outside the region for which small sample size is a problem.
} 
four control predictors only improves the adjusted $R^{2}$ somewhat. At a 3-quarter horizon, the adjusted $R^{2}$ 's for the full regressions for stocks, bonds, and currencies are 10.4 percent, 21 percent, and 11.4 percent, respectively. Table A4 of the Appendix shows that the out-ofsample $R^{2}$ for stocks and bonds are also large in magnitude.

Finally, the economic significance of the balance sheet variables is also large. For the stock market, a standard deviation increase NYCH banks' cash reserve growth today predicts cumulative excess returns that are 5.3 percentage points higher two quarters ahead. Note, the mean cumulative excess return over two quarters is around 6 percent. Likewise, for highgrade railroad bonds, a standard deviation decrease in the change in NYCH banks' LtD ratio today predicts an excess return that is 1.8 percentage points higher the next quarter. Again, considering that the mean excess return for bonds is -1.6 percent, this is a substantial excess return. Lastly, for currencies, a standard deviation increase in LtD growth today forecasts cumulative excess returns that are higher by 47 basis points two quarters in the future. For context, the standard deviation for cumulative currency excess returns at this horizon is 1.42 percent. Across all asset classes, NYCH bank balance sheet conditions forecast substantial excess returns. Further, the estimated effects are relatively stable across time, as shown in Figure A5 of the Appendix, which plots estimated coefficients for stock and bond excess returns using rolling sample windows.

\section{Mechanism Evidence: NYCH Banks' Supply of Margin Loans}

So far, I have presented results showing that changes in NYCH banks' LtD ratio growth or changes in the growth in their cash reserves simply predict excess returns. I now discuss evidence for why this predictability occurs. 


\section{Bank Balance Sheets and Cash Flows}

First, I demonstrate that NYCH bank balance sheet variables do not help predict future cash flows, so their predictive power for asset returns must be coming through discount rate changes. I regress annual dividend growth on lagged changes in the end-of-year loan-deposit ratio for NYCH banks or their end-of-year cash reserves as well as lagged values of annual real GNP growth, the dividend yield, and the earnings price ratio ${ }^{20}$ The results in Table 2 show that NYCH balance sheets contain no marginal information useful for forecasting dividends. The results hold when including lagged values of dividend growth in the regression, as seen in Columns (2) and (4). Further evidence against the cash flow story is the predictability for high-grade bond returns at short horizons. The railroad bonds that compose this index were never in default while they were included in the index, nor were they ever really in danger of defaulting. Therefore, NYCH bank balance sheets provide no information about cash flows for high grade bonds. Since NYCH balance sheets forecast bond excess returns, they must be affecting investor discount rates.

\section{Loan Supply Versus Demand}

I now turn to providing evidence that $\mathrm{NYCH}$ bank liquidity conditions forecast excess returns through frictions on banks' supply of loans rather than through borrowers' demands for loans. First, I show that, for stocks and bonds, it is only when the NYCH banks are near the minimum reserve requirement that changes in the LtD ratio and cash reserves forecast excess returns ${ }^{21}$ This is important because this is when reserves are scarce and NYCH banks' lending is constrained. Therefore, changes in reserve or LtD ratio growth in these times should either lead to the tightening or relaxation of margin traders' borrowing

\footnotetext{
${ }^{20}$ I use annual values because the original dividend data is at an annual frequency.

${ }^{21}$ I focus only on stock and bond excess returns because the quarters when there were no foreign exchange quotes for at least one of the currencies are typically the quarters with low reserves. Exchange quotes were most frequently available for the British pound, and Figure A4 in the Appendix shows that NYCH bank balance sheets primarily forecast excess returns for the British pound when the NYCH banks are near the minimum reserve.
} 
constraints in future periods ${ }^{22}$

Figure 3 shows the additional excess returns one to four quarters ahead predicted by a standard deviation increase in cash reserve growth for stocks and LtD ratio growth for bonds when the NYCH bank reserve-deposit ratio is below or above its median value (approximately 27 percent) at time $t$. Specifically, for these predictive regressions, I follow Baron and Muir (2020) and define new above- and below-median versions of the predictor variables. The above-median variables take their actual values when NYCH banks' reservedeposit ratio is above the sample median and zero otherwise. Conversely, the below-median predictor variables take their actual values in quarters when $\mathrm{NYCH}$ banks' reserve-deposit ratio is below the sample median and zero otherwise. Excess returns are then regressed on the above- and below-median predictors simultaneously. Note that, for both asset classes, the predicted effects are generally statistically significant only for the "below" versions of the NYCH bank balance sheet variables. The unique predictive power in low-reserve states also generally holds for stocks and bonds when I reduce the bound for the low-reserve state, as shown in the Appendix in Figure A3.

While it is important that the results only hold when the NYCH banks are near the reserve requirement, this does not necessarily mean constraints on the supply of margin loans are what determine risk premia in these low-reserve states. In general, the findings so far could be consistent with broader consumption-based asset pricing models. Balance sheet changes could be correlated with future consumption growth, and low-reserve states could be correlated with times when broad risk aversion is high for reasons unrelated to NYCH banks' ability to supply loans. The latter would therefore make the effects of a given change in future consumption growth on risk premia stronger, accounting for the finding of the previous paragraph.

Informally, the time series of the NYCH bank balance sheet variables suggest that correlation with consumption growth does not drive the predictability results. Figure 4

\footnotetext{
${ }^{22}$ Similarly, Myers (1931) notes "[c]all rates rose as reserves fell but when the reserve ratio approached closely to the legal minimum, the rise in call rates [was] greatly accelerated."
} 
shows NYCH banks' year-over-year change in quarterly cash reserves and LtD ratio with solid vertical lines denoting business cycle peaks, according to the NBER or Romer(1994), and dashed vertical lines denoting troughs, based on the same sources. While business cycle peaks often coincide with periods of high LtD ratio changes and contractions in cash reserves, these are not the only times when reserves contract and the LtD ratio grows larger. Likewise, business cycle troughs often align with peaks in cash growth and troughs in the LtD ratio, but these are not the only times when these balance sheet peaks and troughs occur. Similarly, Figure 5 shows that periods with low reserves do not always occur during recessions, either, making it less likely that low-reserve states simply proxy for periods when consumption is relatively low.

Formally, I show that the predictability using NYCH bank balance sheets holds even after controlling for future output growth or the phase of the business cycle. Importantly, the predictability results again only hold when the NYCH banks are near the minimum reserve and their loan supply is likely constrained. Specifically,including GNP growth over the forecast horizon in the predictive regressions does not dampen the statistical or economic significance of the coefficient on the balance sheet variables, as shown in Table 3. As suggested above, this result specifically holds for the short-horizon forecasts only when reserves are low, so the results reported in Table 3 use only this constrained sample. The peak effects are similar in magnitude to those reported above for the full sample without controlling for future GNP growth: at two quarters, a standard deviation increase in the "reserve growth below" variable predicts cumulative excess returns that are 5.6 percentage points higher for stocks and 34 basis points lower for dollars, respectively. Likewise, at one quarter, a standard deviation increase in the "LtD ratio growth below" variable forecasts excess returns that are 2.1 percentage points lower for high-grade railroad bonds. I report similar results using an indicator variable for whether quarter $t$ contains a business cycle peak or trough instead of GNP growth over the forecast horizon in Table A3 of the Appendix.23

\footnotetext{
${ }^{23} \mathrm{NYCH}$ bank balance sheets still forecast excess returns in low-reserve states when using other measures of real activity over the forecast horizon. Controlling for growth in either business failures, real railroad
} 
Several caveats need to be applied in interpreting these results as evidence against NYCH bank balance sheets merely indicating future consumption growth. First, I have used GNP growth rather than aggregate consumption growth due to data availability, although these two variables are likely correlated. Further, it is not aggregate consumption growth that is important, but the consumption of the marginal investor, who is likely to be a wealthy Wall Street trader. Again, it is difficult to know how different their consumption growth would be relative to the aggregate and how it correlated with GNP growth. That said, with asset prices as a leading indicator for the business cycle, it is hard to imagine that their wealth and consumption growth would differ too strongly from GNP growth. Another caveat that is harder to dismiss is that these regressions use actual changes rather than expected changes in future growth. It might be the case that investors expected large drops in consumption that did not materialize when $\mathrm{NYCH}$ bank balance sheets changed. At the same time, this would imply that investors made systematic errors regarding the relationship between NYCH bank balance sheets and future growth over a 40-year period, without ever updating their beliefs.

Further evidence that predictability comes from margin loan supply shifts and not demand shifts can be seen by examining the forecasting power of NYCH bank balance sheets for British equities. For multiple reasons (strong trade and financial ties, joint adherence to the gold standard for most of the era), financial conditions in the U.S. and U.K. at the time were linked. Indeed, I find that, at both the monthly and quarterly frequency, NYCH bank cash reserve or LtD ratio growth Granger cause money market interest rates in London (forecasting London money market rates up to four quarters into the future), just as they do for U.S. money market rates. There were a few a key distinctions between the New York and London money market, though. Because the UK had a lender of last resort while the U.S. did not, aggregate lending in the UK money market was not supply-constrained, according to contemporaries (Spalding, 1922; Sprague, 1913). Further, the need for overnight financing

earnings, total exports, or pig iron production over the forecast horizon does not diminish the forecasting power of the NYCH bank balance sheet variables. 
for securities was much smaller in London compared to New York because transactions were settled on a fortnightly basis in London rather than a daily basis as in New York. ${ }^{24}$

Despite the forecasting power of NYCH bank balance sheets for British money markets, they offer little forecasting ability for excess returns on British equities over the relevant forecast horizon. As shown in Figure 6, when the forecasting regressions are run using the excess returns for UK equities, the pattern of predictability for U.S. equities is not replicated 25 At no point in the first year was the coefficient on the NYCH bank balance sheet variable statistically significant. Compare this to U.S. equities, where the strongest predictability effects come within the first four quarters. While this does not rigorously prove the unique importance of supply constraints for return predictability, it is certainly suggestive of their role.

\section{Margin Loan Growth Versus Other Loans}

I now turn to providing evidence that constraints on the supply of margin loans specifically are responsible for the predictability of excess returns using NYCH bank balance sheets. I rely on the concentration of call loan provision in a small number of NYCH banks at the time for this evidence. As discussed in Section 2, funds for the NYCH banks to use in the call loan market typically came from the deposits of other banks ("bankers' balances"). ${ }^{26}$ Within the NYCH banks, the nine largest holders of bankers' balances always held a sizable majority of the bankers' balances placed within all the NYC national banks, despite being roughly only $1 / 6$ of the total number of NYC national banks (Myers, 1931). Similarly, data on 32 NYC banks cited by Myers (1931) showed that six banks accounted for 61 percent of

\footnotetext{
${ }^{24}$ Michie (1987) notes that "in London with the fortnightly system there was...much less incessant pressure on the money market." Additional evidence that the lack of lender of last resort and daily settlement in the U.S. affected asset prices can be found in Bernstein et al. (2010, 2019).

${ }^{25}$ In addition to the NYCH bank balance sheet variables, the forecasting regressions for British equities include a lagged estimate of the dividend yield, the lagged one-quarter equity excess return, and lagged year-over-year growth in real bank clearings during the quarter.

${ }^{26}$ James (1978) notes that call loans outstanding were about 75 percent of bankers' balances in New York City, exactly what would be expected if all bankers balances were used for call loans except for the 25 percent reserve requirement.
} 
all call loans managed by these banks. At the same time, I find that the large holders of bankers' balances held only 41.5 percent of all $\mathrm{NYCH}$ bank loans and discounts on average.

I collect individual bank balance sheet data for the largest holders of bankers' balances at quarter-end dates between 1880 and 1913 to test whether these banks drive the excess return predictability. I use information from Myers (1931) on the identity of the NYCH banks that were the main holders of bankers' balances at the start of each decade between 1870 and 1910 and then verify for each year, 1880-1913, which banks held the largest amounts of bankers' balances and collect their balance sheet information at quarter-end dates for that year. The Appendix contains a broader comparison of the so-called "bankers' banks" and the other NYCH banks, but here I note that they all faced the same 25 percent minimum reservedeposit ratio requirement and actually kept roughly similar proportions of their deposits as reserves. Both the bankers' banks and the other NYCH banks had a median reserve-deposit ratio around 27 percent during this time with similar variances. Additionally, each type overlapped in whether it was above or below its median reserve-deposit ratio for about 70 percent of the sample period.

I show in Figure 7 that only the liquidity conditions for the NYCH bankers' banks are significant forecasters of excess returns when the balance sheet changes of bankers' banks and other NYCH banks are separate variables in the predictive regressions. I specifically focus on LtD ratio growth when the NYCH bankers' banks are below their median reservedeposit ratio in Figure 7. This is because the liquidity variables used are strongly correlated across NYCH bank types; however, the correlation in LtD ratio growth is essentially zero when the bankers' banks are closer to the reserve requirement. For both stocks and bonds, the effects on excess returns are much stronger for the bankers' banks liquidity conditions and are only statistically significant for the bankers' banks LtD ratio growth. Furthermore, I find that the other NYCH banks do not forecast returns even when they are closer to the reserve requirement specifically (Figure A7 in the Appendix). Given that the bankers' banks supplied the bulk of margin loans, this is strong evidence that it is margin loan supply 
specifically that matters for return predictability from NYCH bank balance sheets. I show in Table A5 in the Appendix that the balance sheets of the country national banks do not forecast excess returns as additional evidence that margin loan supply links bank balance sheets to asset prices during this time period

I summarize the evidence presented above. First (1), the balance sheet variables do not predict future cash flows, pointing to their relevance for discount rates. Second (2), the forecasting results for NYCH bank cash reserve growth and LtD ratio growth only hold when the banks are near the minimum reserve-deposit ratio. A binding (or near-binding) reserve requirement constrains the composition of banks' assets, particularly limiting their loan growth. Third (3), balance sheets continue to be significant predictors in low-reserve states of the world even after controlling for future real economic activity. Fourth (4), while NYCH bank balance sheets forecast money market rates in both the U.S. and U.K., they only forecast excess stock returns in the U.S. Fifth (5), LtD ratio growth for the "bankers' banks" in the NYCH that provided the most margin lending forecast excess returns, while LtD ratio growth for the other NYCH banks does not predict returns. All these facts support the argument that NYCH banks affect the risk-bearing capacity of margin traders, and thus asset returns, through their supply of margin loans, which is sometimes constrained by minimum reserve requirements.

\section{Concluding Remarks}

This paper provides evidence that intermediary frictions still affect asset returns even when these intermediaries are not the marginal investors using the NYCH banks during the National Banking Era as a test case. Measures of the NYCH banks' ability to expand their loan supply forecast excess returns for stocks, bonds, and currencies. This stands in contrast to the main assumption of most intermediary asset pricing models that intermediary frictions

are important because the intermediares are marginal investors (e.g He and Krishnamurthy, 
2013, Adrian and Boyarchenko, 2012, or the stylized model of Haddad and Muir, 2020). The key feature is that these intermediaries provided funding to the marginal investors, and I provide several pieces of evidence showing that NYCH banks' balance sheets affected discount rates because they were the main suppliers of margin loans. In this regard, they are similar to the unconstrained "financiers" of Brunnermeier and Pedersen (2009) except that they did, in fact, face constraints that limited their financing provision at times.

In addition, this paper's findings highlight the importance of intermediaries' liquidity management as a key friction affecting funding and capital markets. These frictions have also gained prominence due to recent events. First, repo markets experienced a brief stress episode in September 2019, with low reserves at the key lending institutions for repo markets a proposed explanation for the market turmoil (Avalos, Ehlers, Eren; 2019 and Correa, Du, Liao; 2020 ). Further, amidst the scramble for liquidity following the global spread of COVID-19, frictions in funding markets may have affected the price of longer-term assets, including U.S. Treasuries (He et al., 2020).

As a result, this paper has implications for modern-day liquidity regulations and lenderof-last-resort provisions. As noted by Hanson et al. (2015), the national banks are similar in many ways to the so-called "shadow" banking institutions today. They lack access to a lender of last resort and the government does not insure their liabilities, but regulations manage the liquidity of their assets to prevent intermediaries from becoming illiquid and creating problems for the broader financial system. In both the historical and modern case, it would appear these regulations have not been entirely successful. For example, despite additional liquidity regulations imposed after the GFC, many shadow banking institutions still faced liquidity problems that spilled over into broader asset prices during the rapid spread of COVID-19. Like in the GFC, the Federal Reserve had to step in and provide additional liquidity in the markets where these shadow banks primarily operate. In general, liquidity regulations have been understudied, especially compared to capital requirements (Allen and Gale, 2017; Diamond and Kashyap, 2016). The results of this paper suggest 
future work should focus on the effectiveness of liquidity regulations without an explicit lender of last resort.

\section{References}

Adrian, Tobias and Nina Boyarchenko. (2012). "Intermediary Leverage Cycles and Financial Stability," Federal Reserve Bank of New York Staff Report No. 567.

Adrian, Tobias, Erkko Etula, and Tyler Muir. (2014). "Financial Intermediaries and the Cross-Section of Asset Returns," Journal of Finance 69(6): 2557-2596.

Adrian, Tobias, Erkko Etula, and Hyun Song Shin. (2015). "Risk Appetite and Exchange Rates," Federal Reserve Bank of New York Staff Report No. 361.

Adrian, Tobias, Emanuel Moench, and Hyun Song Shin. (2019). "Dynamic Leverage Asset Pricing," Center for Economic Policy Research Discussion Paper No. 11466.

Allen, Franklin and Douglas Gale. (2017). "How Should Bank Liquidity Be Regulated?" Mimeo.

Anderson, Haelim, Mark Paddrik, and Jessie Jiaxu Wang. (2019). "Bank Networks and Systemic Risk: Evidence from the National Bank Acts," American Economic Review 109(9): 325-361.

Avalos, Fernando, Torsten Ehlers, and Egemen Eren. (2019). "September Stress in Dollar Repo Markets-Passing or Structural?" BIS Quarterly Review December 2019: 12-14.

Baron, Matthew and Tyler Muir. (2020). "Intermediaries and Asset Prices: Evidence from the U.S., U.K., and Japan, 1870-2016," Mimeo.

Bernstein, Asaf, Eric Hughson, and Marc D. Weidenmier. (2010). "Identifying the Effects of a Lender of Last Resort on Financial Markets: Lessons from the Founding of the Fed," Journal of Financial Economics 98(1): 40-53.

Bernstein, Asaf, Eric Hughson, and Marc D. Weidenmier. (2019). "Counterparty Risk and the Establishment of the New York Stock Exchange Clearinghouse," Journal of Political Economy 127(2): 689-729.

Bianchi, Javier and Saki Bigio. (2018). "Banks, Liquidity Management and Monetary Policy," Mimeo.

Bigio, Saki and Yuliy Sannikov. (2019). "A Model of Intermediation, Money, Interest and Prices," Mimeo. 
Brunnermeier, Markus and Lasse H. Pedersen. (2009). "Market Liquidity and Funding Liqudity," Review of Financial Studies 22(6): 2201-2238.

Calomiris, Charles W. and Mark Carlson. (2017). "Interbank Networks in the National Banking Era: Their Purpose and Their Role in the Panic of 1893," Journal of Financial Economics 125(3): 434-453.

Campbell, John Y. and Motohiro Yogo. (1999). "Efficient Tests of Stock Return Predictability," Journal of Financial Economics 81(1): 27-60.

Chabot, Benjamin. (2011). "The Cost of Banking Panics in an Age before 'Too Big to Fail'," Federal Reserve Bank of Chicago Working Paper 2011-15.

Cleveland, Frederick A. (1908). The Bank and the Treasury: Bank Capitalization and the Problem of Elasticity. New York: Longmans, Green, and Co.

Coleman, Andrew. (2012). "Uncovering Uncovered Interest Parity during the Classical Gold Standard Era, 1888-1905," North American Journal of Economics and Finance 23(1): 2037.

Correa, Ricardo and Laurie P. Demarco. (2019). "Dealer Leverage and Exchange Rates: Heterogeneity Across Intermediaries," International Finance Discussion Papers 1262.

Correa, Ricardo, Wenxin Du, and Gordon Liao. (2020) "US Banks and Global Liquidity," International Finance Discussion Papers 1289.

d'Avernas, Adrien, Quentin Vandeweyer, and Matthieu Darracq Pariès. (2020). "Central Banking with Shadow Banks," Mimeo.

Diamond, Douglas W. and Anil K. Kashyap. (2016). "Liquidity Requirements, Liquidity Choice, and Financial Stability." In Taylor and Uhlig, Eds., Handbook of Macroeconomics, Volume 2. Elsevier.

Drechsler, Itamar, Alexi Savov, and Phillip Schnabl. (2018). "A Model of Monetary Policy and Risk Premia," Journal of Finance 73(1): 317-373.

Du, Wenxin, Benjamin Hébert, and Amy W. Huber. (2018). "Are Intermediary Constraints Priced?" Mimeo.

Duffie, Darrell. (2010). "The Failure Mechanics of Dealer Banks," Journal of Economic Perspectives 24(1): 51-72.

Dunbar, Charles F. (1891). Chapters on the Theory and History of Banking. New York: G.P. Putnam's Sons.

Fohlin, Caroline, Thomas Gehrig, Marlene Haas. (2016). "Rumors and Runs in Opaque Markets: Evidence from the Panic of 1907," CESifo Working Paper No. 6048.

Gârleanu, Nicolae and Lasse H. Pedersen. (2011). "Margin-based Asset Pricing and Deviations from the Law of One Price," Review of Financial Studies 24(6): 1980-2022. 
Geanakoplos, John. (2010). "The Leverage Cycle." In Acemoglu and Woodford, Eds., NBER Macroeconomics Annual 2009. University of Chicago Press.

Goetzmann William N., Roger G. Ibbotson, Liang Peng. (2001). "A New Historical Database for the NYSE 1815 to 1925: Performance and Predictability," Journal of Financial Markets 4(1): 1-32.

Goodhart, Charles A.E. (1969). The New York Money Market and the Finance of Trade 1900-1913. Cambridge: Harvard University Press.

Gorton, Gary, Toomas Laarits, and Tyler Muir. (2020). "Mobile Collateral Versus Immobile Collateral," Mimeo.

Goyal, Amit and Ivo Welch. (2008). "A Comprehensive Look at the Empirical Performance of Equity Premium Prediction," Review of Financial Studies 21(4): 1455-1508.

Griffiss, Bartow. (1925). The New York Call Money Market. New York: Ronald Press Company.

Haddad, Valentin and Tyler Muir. (2020). "Do Intermediaries Matter for Aggregate Asset Prices?" Mimeo.

Hanes, Christopher and Paul W. Rhode. (2013). "Harvests and Financial Crises in GoldStandard America," Journal of Economic History 73(1): 201-246.

Hanson, Samuel, Andrei Shleifer, Jeremey Stein, and Robert Vishny. (2015). "Banks as Patient Fixed-Income Investors," Journal of Financial Economics 117(3): 449-469.

He, Zhiguo, Bryan Kelly, and Asaf Manela. (2017). "Intermediary Asset Pricing: New Evidence from Many Asset Classes," Journal of Financial Economics 126(1): 1-35.

He, Zhiguo and Arvind Krishnamurthy. (2013). "Intermediary Asset Pricing," American Economic Review 103(2): 732-770.

He, Zhiguo and Arvind Krishnamurthy. (2018). "Intermediary Asset Pricing and the Financial Crisis," Annual Review of Financial Economics 10: 173-197.

He, Zhiguo, Stefan Nagel, and Zhaogang Song. (2020). "Treasury Inconvenience Yields during the Covid-19 Crisis," NBER Working Paper No. 27416.

Hodrick, Robert J. (1992). "Dividend Yields and Expected Stock Returns: Alternative Procedures for Inference and Measurement," Review of Financial Studies 5(3): 357-386.

James, John A. (1978). Money and Capital Markets in Post-Bellum America. Princeton University Press.

Jaremski, Matthew and Peter L. Rousseau. (2018) "The Dawn of an 'Age of Deposits' in the United States," Journal of Banking and Finance 87: 264-281. 
Jordà, Òscar, Björn Richter, Moritz Schularick, and Alan M. Taylor. (2017). "Bank Capital Redux: Solvency, Liquidity, and Crisis," NBER Working Paper 23287.

Kahraman, Bige and Heather E. Tookes. (2017). "Trader Leverage and Liquidity," Journal of Finance 72(4): 1567-1610.

Macaulay, Frederick R. (1938). Some Theoretical Problems Suggested by the Movements of Interest Rates, Bond Yields and Stock Prices in the United States since 1856. New York: National Bureau of Economic Research.

Michie, Ranald C. (1987). The London and New York Stock Exchanges, 1850-1914. London: Allen and Unwin.

Moen, Jon R. and Ellis W. Tallman. (2003). "The Call Loan Market in the U.S. Financial System Prior to the Federal Reserve System," Federal Reserve Bank of Atlanta Working Paper 2003-43.

Myers, Margaret. (1931). The New York Money Market. New York: Columbia University Press.

Piazzesi, Monika and Martin Schneider. (2018) "Payments, Credit and Asset Prices," Mimeo.

Romer, Christina D. (1994). "Remeasuring Business Cycles," Journal of Economic History 54(3): 573-609.

Spalding, William F. (1922). The London Money Market. London: Sir Isaac Pitman \& Sons.

Sprague, Oliver M.W. (1913). Lectures on Banking and Finance. New York: American Institute of Banking. 
Figure 1:

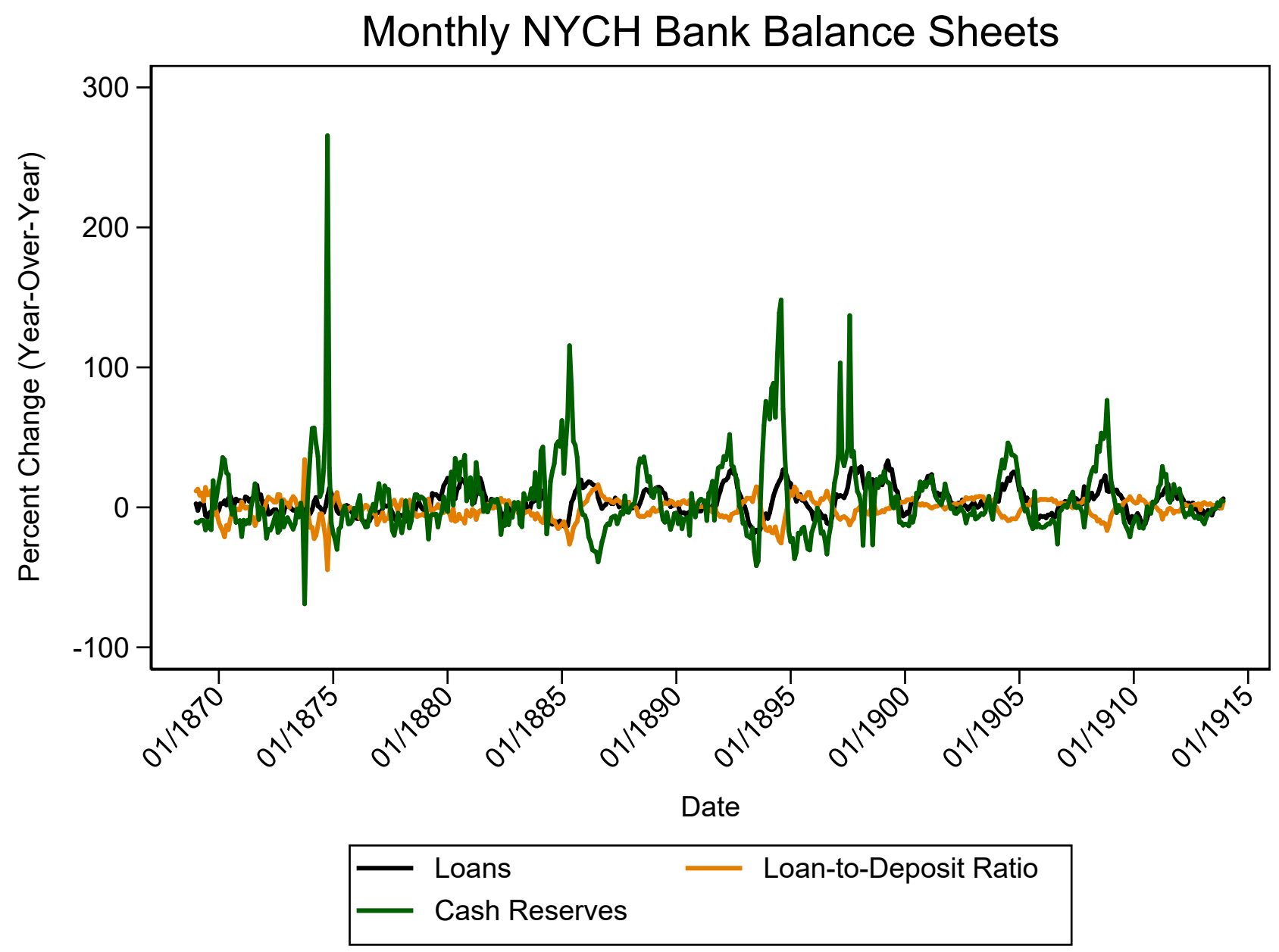

Figure plots monthly year-over-year percent changes in NYCH banks' loans, cash reserves, and loan-to-deposit ratio from 1869 to 1913. 
Figure 2: Excess Return Forecasts at Quarterly Horizons
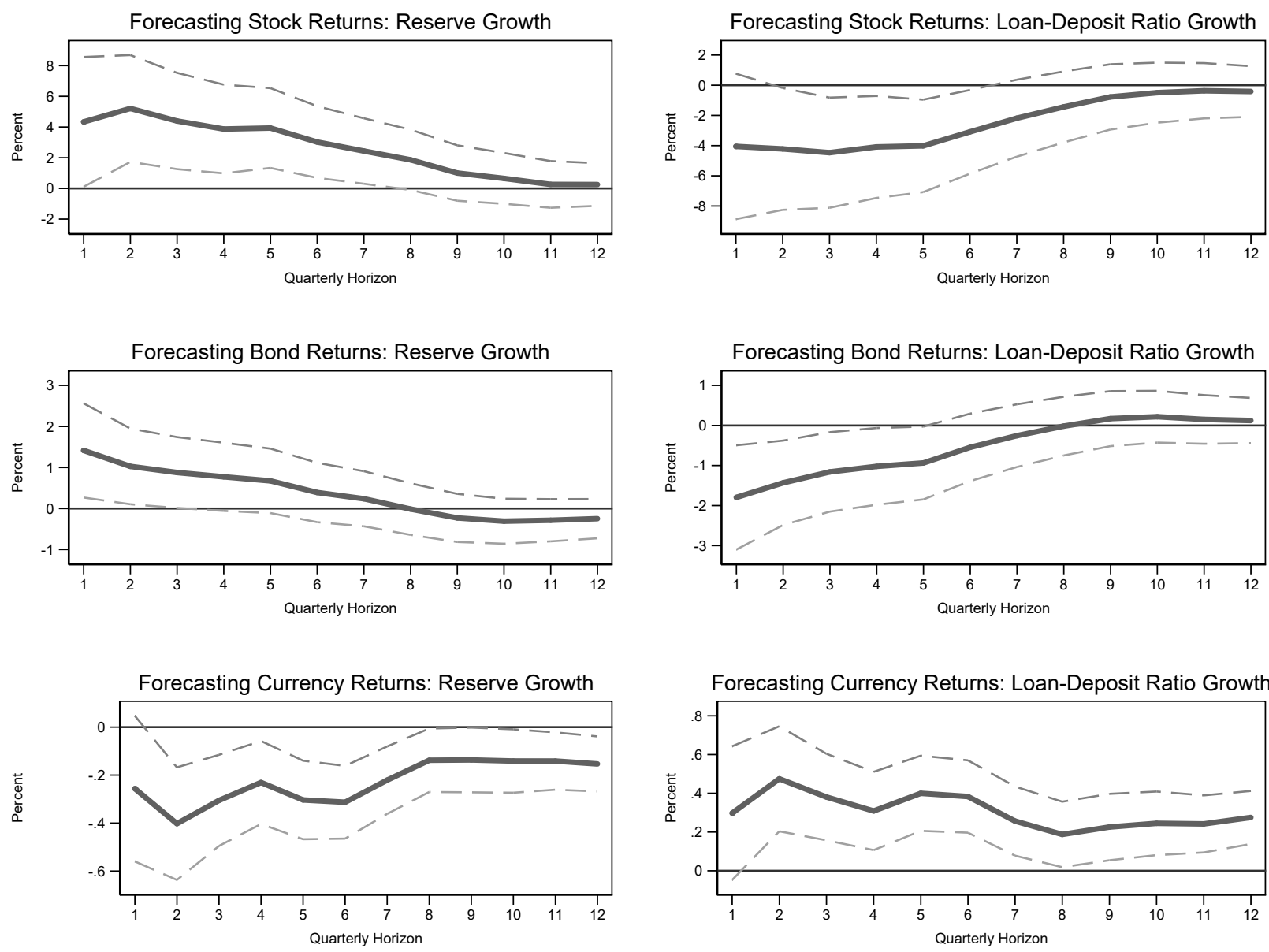

Each panel shows the additional cumulative excess return at quarterly horizon $t+h$ for a specific asset class predicted by a standard deviation increase in a given NYCH bank balance sheet variable at time $t$ : year-over-year cash reserve growth or year-over-year loan-to-deposit ratio growth. Estimates are based on equation (1), with controls for year-over-year RGNP growth, one-quarter excess return, dividend yield, and earnings-to-price ratio, all measured at time $t$. Dashed lines are 90\% confidence bands computed using Hodrick (1992) standard errors. 
Figure 3: Excess Return Forecasts When Reserve-Deposit Ratio Is Below or Above Median
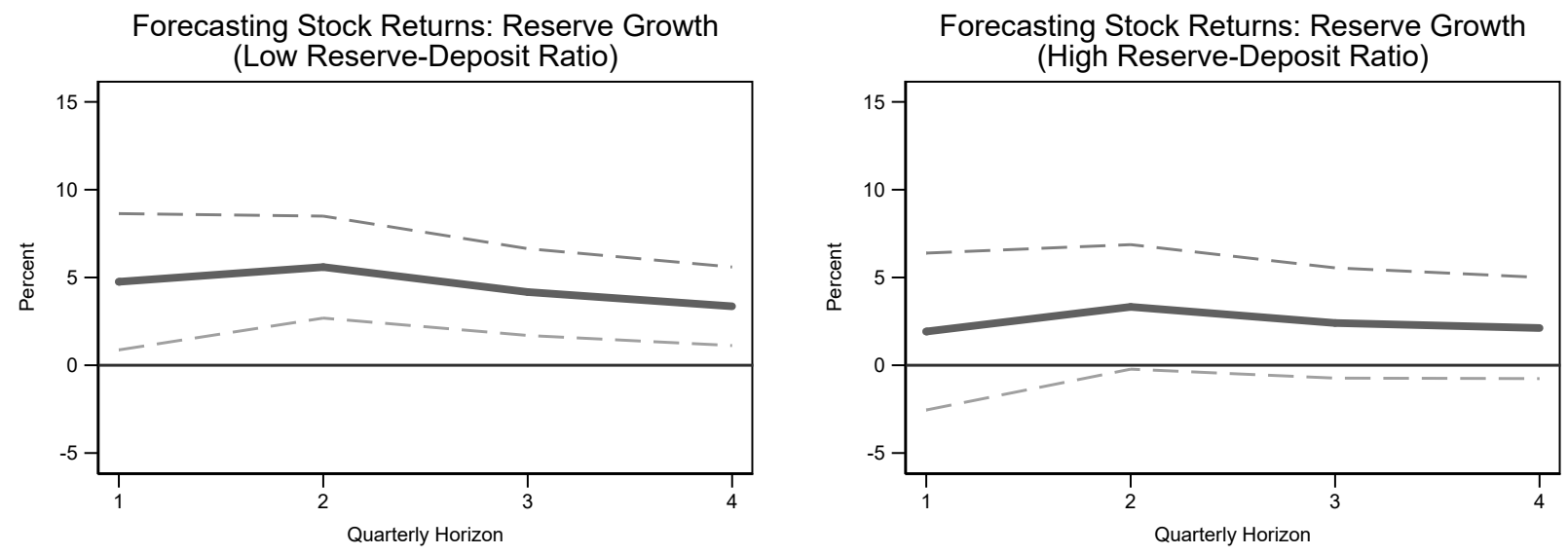

Forecasting Bond Returns: Loan-Deposit Ratio Growth (Low Reserve-Deposit Ratio)

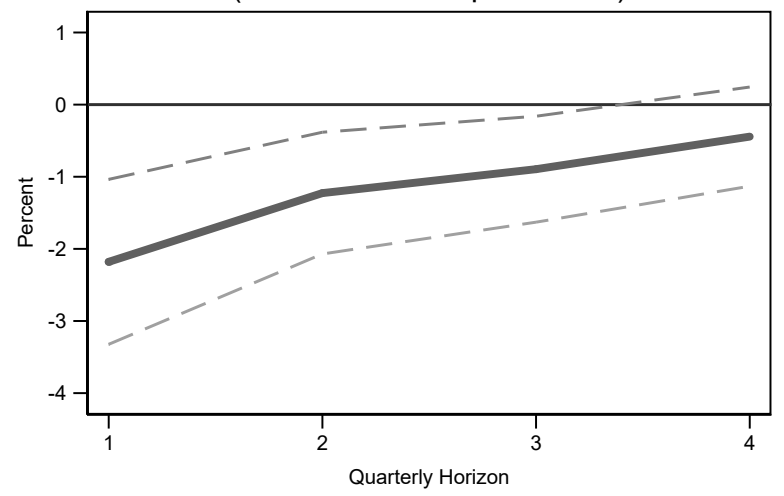

Forecasting Bond Returns: Loan-Deposit Ratio Growth (High Reserve-Deposit Ratio)

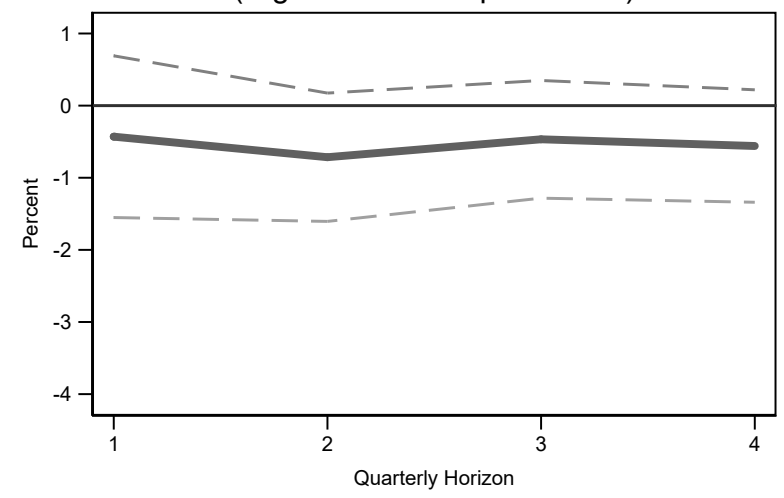

Each panel shows the additional cumulative excess return at quarterly horizon $t+h$ for a specific asset class predicted by a standard deviation increase in a given $\mathrm{NYCH}$ bank balance sheet variable at time $t$ : year-over-year cash reserve growth or year-over-year loan-to-deposit ratio growth. Estimates are based on a modified version of equation (1) where each original regressor is transformed into two new variables: one that is the original value when NYCH banks' reserve-deposit ratio is below its sample median and 0 otherwise and another that is the original value when $\mathrm{NYCH}$ banks' reserve-deposit ratio is above its sample median and 0 otherwise. Left panels report the predicted additional excess returns using the "below" versions of NYCH bank balance sheet variables, and right panels report results for "above" versions of NYCH bank balance sheet variables. Dashed lines are $90 \%$ confidence bands computed using Hodrick (1992) standard errors. 
Figure 4:

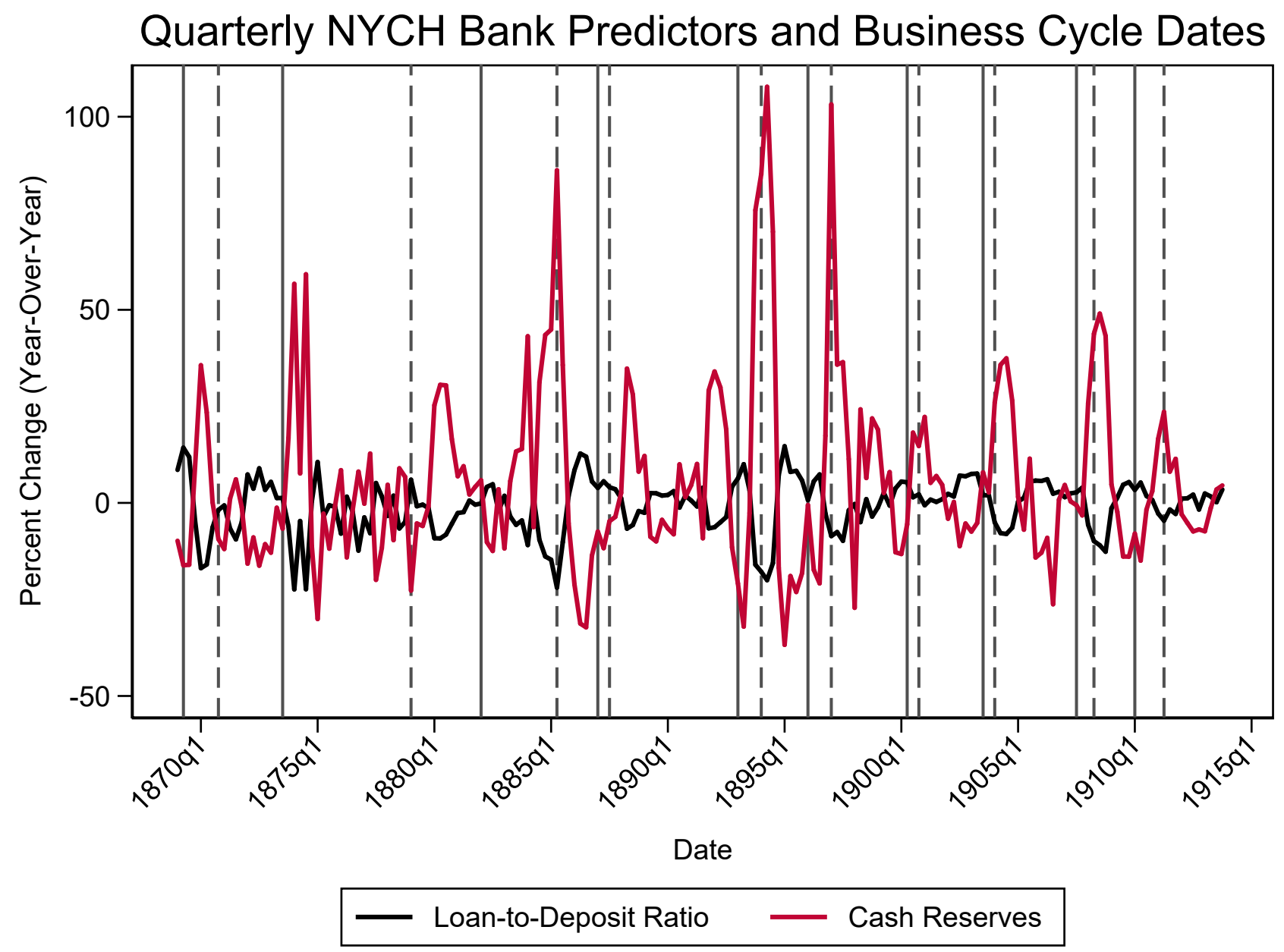

Figure plots quarterly year-over-year percent changes in NYCH banks' cash reserves and loan-to-deposit ratio. Solid vertical lines are quarters with business cycle peaks according to NBER or Romer (1994). Dashed vertical lines are quarters with business cycle troughs according to NBER or Romer (1994). 
Figure 5:

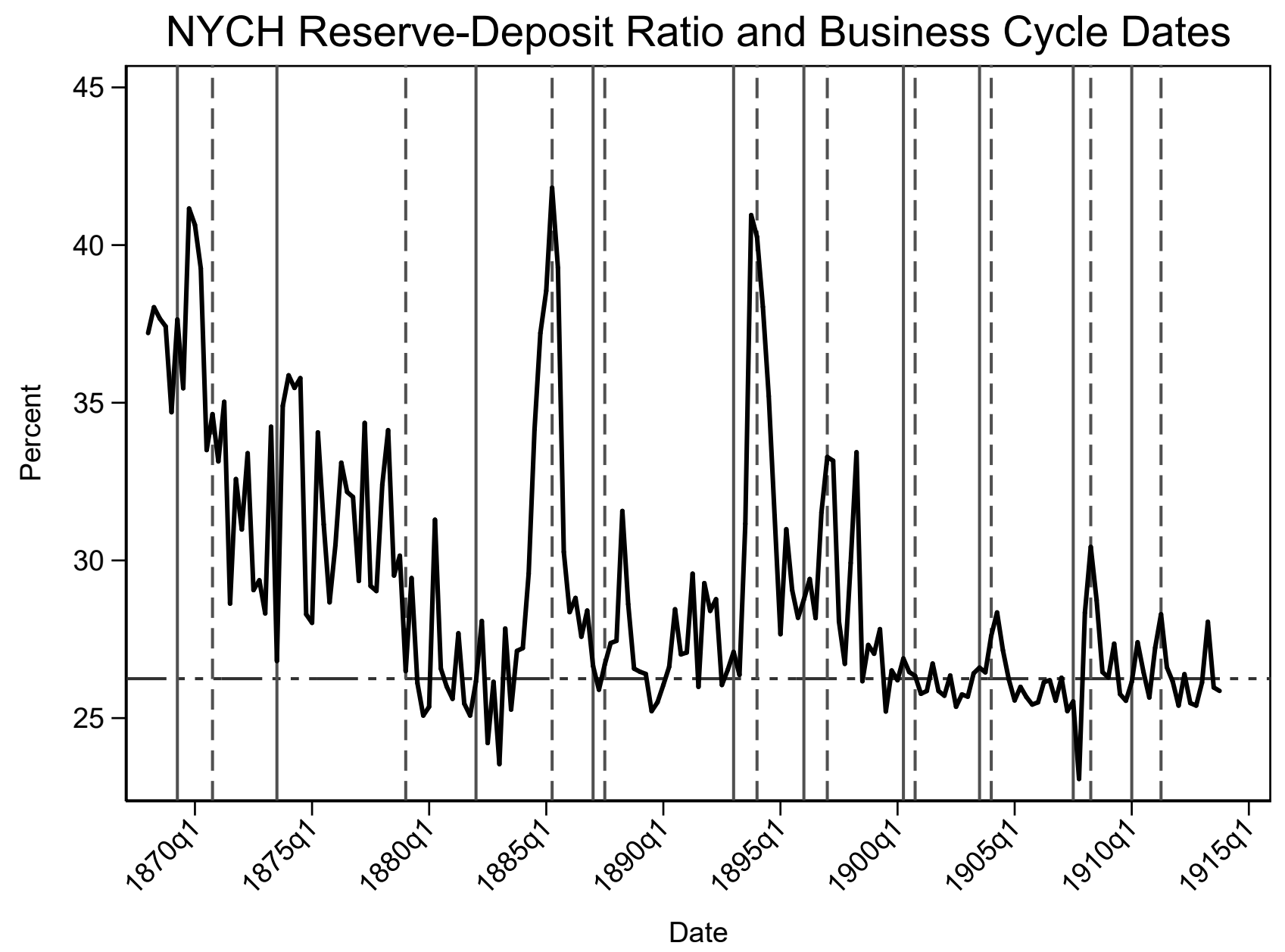

Figure plots end of quarter reserve-deposit ratio for NYCH banks. Horizontal line marks 25th percentile for this ratio. Solid vertical lines are quarters with business cycle peaks according to NBER or Romer (1994). Dashed vertical lines are quarters with business cycle troughs according to NBER or Romer (1994). 
Figure 6:

Forecasting UK Stock Returns: Reserve Growth

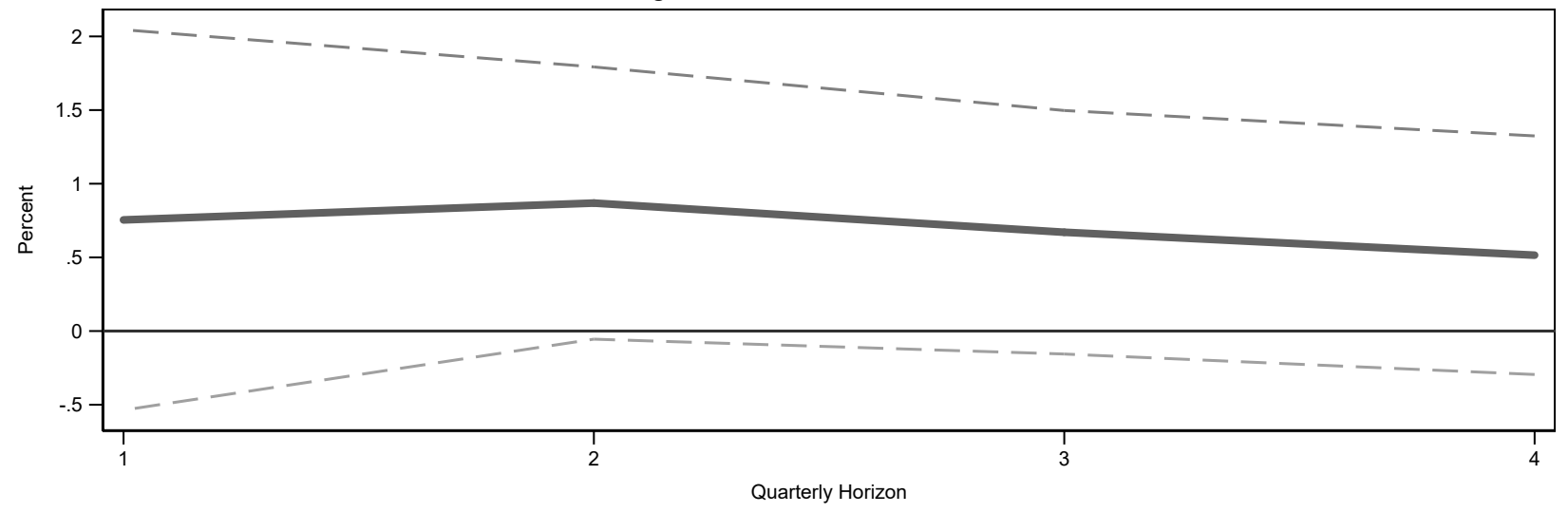

Forecasting UK Stock Returns: Loan-Deposit Ratio Growth

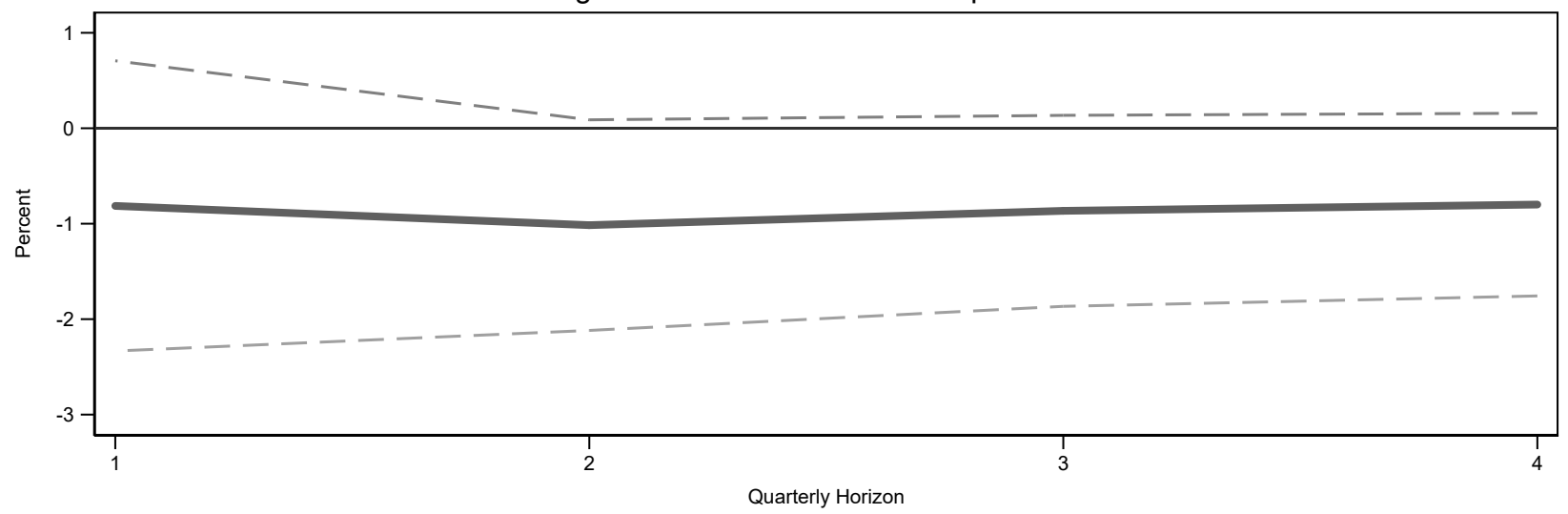

Each panel shows the additional cumulative excess return at quarterly horizon $t+h$ for British equities predicted by a standard deviation increase in a given NYCH bank balance sheet variable at time $t$ : year-over-year cash reserve growth or year-over-year loan-to-deposit ratio growth. Estimates are based on regressions of cumulative excess returns for British equities at $t+h$ on the NYCH bank balance sheet variable at time $t$, year-over-year growth in real British bank clearings at time $t$, the dividend yield for British equities at time $t$, and the one-quarter excess return for British equities at time $t$. Dashed lines are $90 \%$ confidence bands computed using Hodrick (1992) standard errors. 
Figure 7: Excess Return Forecasts for Different NYCH Bank Groups
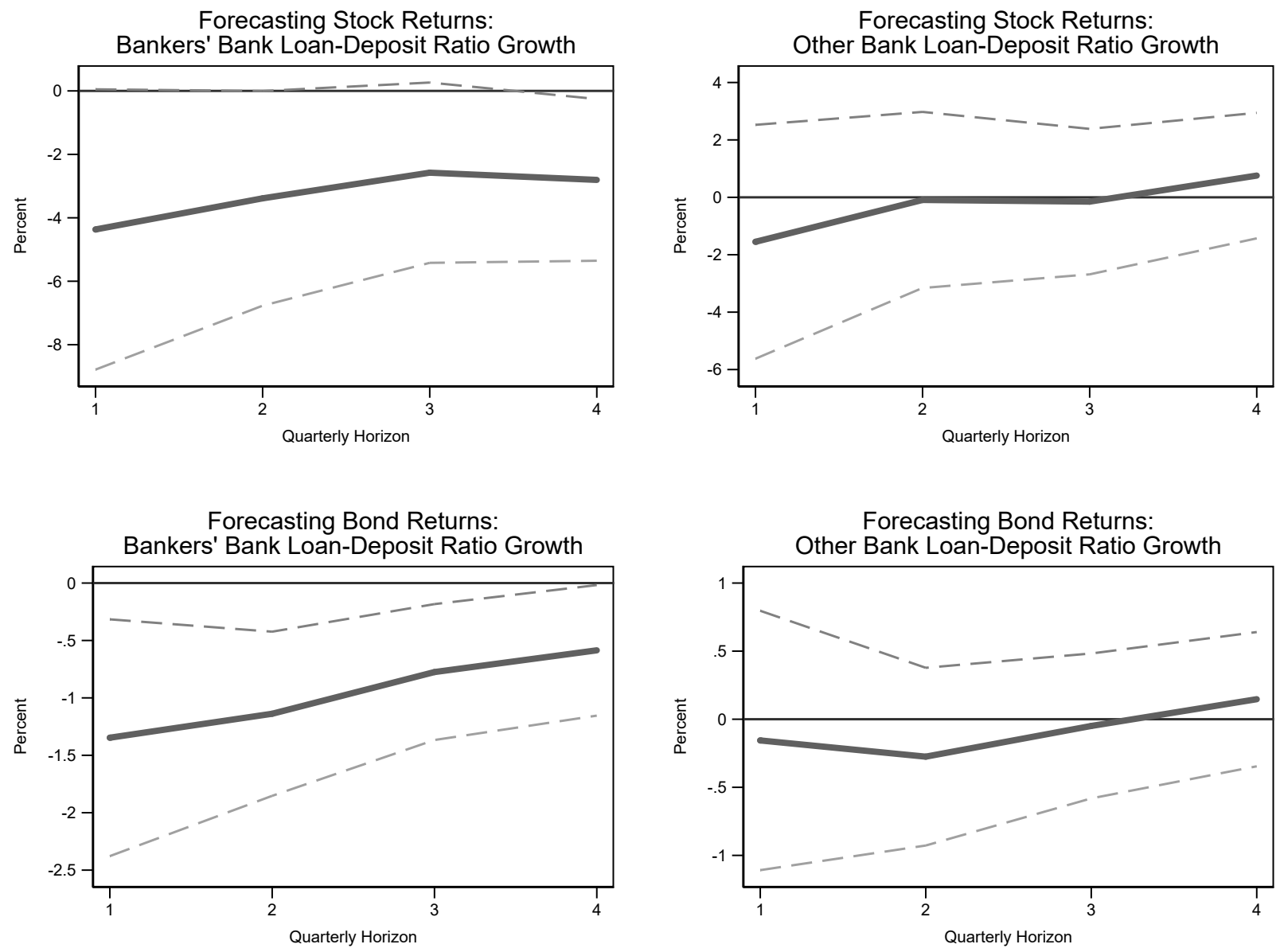

Each panel shows the additional cumulative excess return at quarterly horizon $t+h$ for a specific asset class predicted by a standard deviation increase in either NYCH "bankers' banks" year-over-year loan-to-deposit ratio growth or all other NYCH banks' year-over-year loan-to-deposit ratio growth at time $t$. Estimates are based on regression of cumulative excess returns at $t+h$ on NYCH bankers' bank and other NYCH banks' year-over-year loan-to-deposit ratio growth, year-over-year real GNP growth, dividend yield, earnings-price ratio, and one quarter excess return, all measured at time $t$. All regressions run using "below" and "above" versions of each regressor, where "below" variables are their original value when NYCH bankers' banks' reserve-deposit ratio is below its sample median and 0 otherwise and "above" variables are their original values when NYCH bankers' banks' reserve-deposit ratio is above its sample median and 0 otherwise. Panels report additional predicted excess returns for "below" versions of bank balance sheet variables. Dashed lines are 90\% confidence bands computed using Hodrick (1992) standard errors. 
Table 1: Granger Causality Test P-Values

\begin{tabular}{lll}
\hline & 2 Lags & 12 Lags \\
\hline \hline LtD Ratio & 0.000 & 0.000 \\
Cash Reserves & 0.000 & 0.000 \\
\hline
\end{tabular}

Notes: Reported p-values are for null hypothesis each variable does not Granger cause year-over-year percentage change in NYCH bank loans and discounts. Monthly vector autoregressions (VARs) are run separately with NYCH bank loan growth and either NYCH bank loan-to-deposit ratio year-over-year changes or NYCH bank cash reserve year-over-year percent changes as the second variable in the system. Column "2 lags" is for a VAR with 2 lags; Column "12 lags" is for a VAR with 12 lags.

Table 2: Forecasts of Dividend Growth with Predictor Variables

\begin{tabular}{lllll}
\hline & $(1)$ & $(2)$ & $(3)$ & $(4)$ \\
\hline \hline Loan-to-Deposit Ratio & 1.08 & 1.38 & & \\
& $(1.94)$ & $(2.18)$ & & \\
Cash Reserves & & & 0.31 & -0.41 \\
& & & $(1.87)$ & $(1.91)$ \\
\hline Lagged Dividend Change? & $\mathrm{N}$ & $\mathrm{Y}$ & $\mathrm{N}$ & $\mathrm{Y}$ \\
\hline
\end{tabular}

Notes: This table reports results of regressions of annual dividend growth (in percentage terms) on the lagged value of the end-of-year NYCH bank loan-to-deposit ratio change (Columns (1) and (2)) or end-ofyear NYCH bank cash reserve percent change (Columns (3) and (4)), as well as the lagged annual growth rate of real GNP, the lagged dividend yield, and the lagged earnings-price ratio. Columns (2) and (4) also include the lagged percentage change of the dividend as a regressor. Reported coefficients are for a standard deviation increase in the NYCH bank variable. Dividends are for all stocks listed on the New York Stock Exchange. Newey-West standard errors using four lags in parentheses. ${ }^{* * *} \mathrm{p}<0.01,{ }^{* *} \mathrm{p}<0.05,{ }^{*} \mathrm{p}<0.1$. 
Table 3: Return Predictability with Low Reserves and Future GNP Growth

\begin{tabular}{|c|c|c|c|c|}
\hline & 1Q-Ahead & 2Q-Ahead & 3Q-Ahead & 4Q-Ahead \\
\hline Stocks (LtD) & $\begin{array}{l}-4.55^{*} \\
(2.52)\end{array}$ & $\begin{array}{l}-5.47^{* * *} \\
(1.86)\end{array}$ & $\begin{array}{l}-3.38^{* *} \\
(1.58)\end{array}$ & $\begin{array}{l}-2.52^{*} \\
(1.39)\end{array}$ \\
\hline Stocks (Cash) & $\begin{array}{l}4.37^{* *} \\
(2.23)\end{array}$ & $\begin{array}{l}5.53^{* * *} \\
(1.60)\end{array}$ & $\begin{array}{l}3.70^{* * *} \\
(1.35)\end{array}$ & $\begin{array}{l}3.03^{* * *} \\
(1.16)\end{array}$ \\
\hline Bonds (LtD) & $\begin{array}{l}-2.13^{* * *} \\
(0.70)\end{array}$ & $\begin{array}{l}-1.15^{* *} \\
(0.51)\end{array}$ & $\begin{array}{l}-0.85^{*} \\
(0.45)\end{array}$ & $\begin{array}{l}-0.45 \\
(0.42)\end{array}$ \\
\hline Bonds (Cash) & $\begin{array}{l}1.27^{* *} \\
(0.61)\end{array}$ & $\begin{array}{l}0.66 \\
(0.45)\end{array}$ & $\begin{array}{l}0.55 \\
(0.39)\end{array}$ & $\begin{array}{l}0.16 \\
(0.36)\end{array}$ \\
\hline Currency (LtD) & $\begin{array}{l}0.29 \\
(0.20)\end{array}$ & $\begin{array}{l}0.36^{* *} \\
(0.14)\end{array}$ & $\begin{array}{l}0.27^{* *} \\
(0.12)\end{array}$ & $\begin{array}{l}0.22^{\text {** }} \\
(0.10)\end{array}$ \\
\hline Currency (Cash) & $\begin{array}{l}-0.30^{*} \\
(0.18)\end{array}$ & $\begin{array}{l}-0.34^{* * *} \\
(0.13)\end{array}$ & $\begin{array}{l}-0.23^{* *} \\
(0.10)\end{array}$ & $\begin{array}{l}-0.15^{*} \\
(0.10)\end{array}$ \\
\hline
\end{tabular}

Notes: Table reports coefficients for estimates of modified version of equation (1) with real GNP growth over the forecast horizon included as an additional regressor and each variable transformed into two versions of itself: a "below" version that is the original value when $\mathrm{NYCH}$ banks' reserve-deposit ratio is below its sample median and 0 otherwise and an "above" version that is the original value when NYCH banks' reserve-deposit ratio is above its sample median and 0 otherwise. Rows are for different asset class-NYCH balance sheet variable pairs. (LtD) means the NYCH bank balance sheet variable is the year-over-year change in the end-of-quarter loan-to-deposit ratio. (Cash) means the NYCH bank balance sheet variable is the year-over-year percentage growth in end-of-quarter cash reserves. Coefficients show effect of standard deviation increase in "below" version of NYCH bank balance sheet variable. Hodrick (1992) standard errors in parentheses. ${ }^{* *} \mathrm{p}<0.01,{ }^{* *} \mathrm{p}<0.05,{ }^{*} \mathrm{p}<0.1$. 


\section{A Appendix}

\section{Bank Balance Sheets and Asset Prices: Contemporary Accounts}

Contemporaries of the National Banking Era recognized the importance of credit conditions for asset prices, with the health of the $\mathrm{NYCH}$ banks explicitly emphasized by many. One way to observe this is in the content of guides to Wall Street and investing. Both Pratt (1912) and Selden (1917) contain individual chapters dedicated to banks and bank statements, for instance. In both cases, the focus is primarily on the NYCH banks, with each guide claiming that the weekly statement of the NYCH banks is only rivaled by the Bank of England's weekly statement in terms of importance. Why give so much weight to the bank statement? Pratt (1912) argues: "as a general rule, any shortage in the supply of credit checks stock speculation and produces declines in prices...If the contraction is so extreme as to make it impossible to arrange loans, large blocks of securities, which can not be carried, are dumped on the market for what they will bring, and the Street then has a panic. Wall Street therefore scrutinizes the bank statement with the utmost care."

What aspects of the bank statement received the most attention by investors? According to Selden (1917), "The figures most closely watched by Wall Street are the surplus reserve and the relation between 'Net Demand Deposits' and 'Loans, Discounts, Investments, etc."' For the NYCH national banks, reserves had to be held either in the form of specie or legal tender. Pratt (1912) notes "More significant than all the other items of a bank statement therefore are those representing cash holdings. Credit may be the vital air of the whole financial system, but money is the oxygen in the air, without which there would be suffocation and death...An increase in cash increases the credit-giving power of the banks. A decrease in cash involves a contraction of credit." Likewise, Selden (1917) argues that the strength of a bank's cash position is "carefully watched as an index to the supply of money available for loans." In addition, for Selden (1917), “...if deposits exceed loans, a very strong position is shown; but when the loans begin to show a large excess over deposits the situation 
will bear watching."

Even without separate chapters on the NYCH banks, other investment guides acknowledged the role credit conditions play in determining asset prices. Again, they placed emphasis on NYCH banks' cash reserves and the ratio of loans to deposits as important barometers for credit. On the importance of reserves, Hall (1909) simply states "When reserves have fallen below the legal limit, the loaning power of the banks is ended for the time being. If reserves show a deficit, the banks are perforce obliged to call in a part of their loans. Stock speculators are then obliged to throw overboard a part of their loads in order to raise funds wherewith to repay their loans. Selling of this compulsory character invariably means a slump in the stock market and possibly a long decline." Similarly, for the relationship between loans and deposits, Hall (1909) emphasizes the excess of deposits relative to loans (surplus deposits). He argues that "when surplus deposits are dangerously low, a situation is revealed which may and commonly does foreshadow a serious decline in stocks or an actual crisis. The catastrophe may be postponed for a year or more, but it is sure to arrive." Chamberlain (1911) also emphasized the loan-to-deposit ratio, as it represented "the ratio of the demand for to the supply of credit...High ratio means necessity for liquidation by borrowers; low ratio, power for accumulation."

The relationship between the banking system and financial markets also received special attention by commissions called by multiple levels of government after the Panic of 1907, a severe financial crisis in the U.S. One publication produced by the National Monetary Commission was Hollander (1911), aptly titled Bank Loans and Stock Exchange Speculation. The fifth chapter specifically focuses on "speculative purchases of stock exchange securities" financed especially by "demand loans obtained from banking institutions and secured by such securities as collateral" (Hollander, 1911). Similarly, in 1909, the governor of New York appointed a commission to study speculation in securities and commodities. The report by this commission also discussed the relationship between the money market and stock exchange speculation (Pratt, 1912). 


\section{Narrative evidence on NYCH Bank Balance Sheet Changes}

Section 3 discusses three reasons for changes in liquidity conditions for the NYCH banks. Here, I highlight narrative evidence on the role these factors played in quarters with large changes in NYCH banks' cash positions, relatively low reserves, and subsequently large positive or negative excess returns on stocks and bonds in future quarters. This is not an exhaustive summary for all quarters, rather it draws from the historical record for a few quarters that fit the pattern identified in the forecasting regressions particularly well.

First, the second half of 1880 featured large increases in the cash reserves of the NYCH banks at a time when the aggregate reserve-deposit ratio for the $\mathrm{NYCH}$ banks hovered near 26 percent. Annualized two-quarter cumulative excess stock returns were 49 and 29 percent in 1881:Q1 and 1881:Q2. The annualized excess one-quarter bond return in 1880:Q4 was 30.8 percent. In an article on the effect of crop harvests on business conditions in the U.S., Andrew (1906) describes how the harvests for the three most important crops (corn, wheat, cotton) "exceeded even the levels of 1879, and the foreign crops again ran short." With such a large harvest in the U.S. and small harvests elsewhere, it meant "incoming gold and expanded credit."

Conversely, the end of the second quarter of 1890 marked a decline of NYCH bank cash reserves, while the aggregate reserve-deposit ratio stood at 26.63 percent. Annualized two-quarter cumulative stock excess returns in 1890:Q4 were -32.9 percent. Similarly, the annualized one-quarter excess return on bonds in 1890:Q3 was -10.3 percent. The Commercial and Financial Chronicle summarized the situation thusly: "We are exporting gold, and though not in large amounts at present, yet with our surplus reserve only a little in excess of 6 million dollars, every shipment is felt. Then too the Government has again been drawing

on the banks, and this week the net amount taken is in excess of the takings last week. If to these inuences we add the current business demand which is more urgent than a year ago and which has in past weeks had some inuence in keeping the currency ow from the interior to this center smaller than it was last year, it is not difficult to account for any increase of 
activity in money which is noticed."

Finally, the third quarter of 1906 also featured a sharp decline in NYCH banks cash reserves while the reserve-deposit ratio was 26.2 percent. Annualized two-quarter cumulative stock excess returns in 1907:Q1 were -32.6 percent, while the annualized one-quarter bond excess return in 1906:Q4 was -3.3 percent. Again, the Commercial and Financial Chronicle provides a useful summary of the factors driving reserve changes: "Money again developed decided tension. The New York City banks had to meet the usual call for funds to move the crops, while at the same time the U. S. Treasury was taking money out of the banks." 


\title{
Data Sources and Construction
}

\author{
Table A1: Data Sources

\begin{tabular}{|c|c|}
\hline Variable & Details \\
\hline $\begin{array}{l}\text { NYCH } \\
\text { Bank Cash } \\
\text { Reserves, } \\
\text { Loans, } \\
\text { Deposits }\end{array}$ & $\begin{array}{l}\text { Sources: Statistics for the United States, 1867-1909: pp. } 75-118 \\
\text { and Commercial and Financial Chronicle: various issues. Cash } \\
\text { reserves are "specie and legal tender." Loans are the "loans and } \\
\text { discounts" line. Deposits are "net deposits." }\end{array}$ \\
\hline $\begin{array}{l}\text { Country } \\
\text { Bank Cash } \\
\text { Reserves }\end{array}$ & $\begin{array}{l}\text { Source: NBER Macrohistory database series m14011. Variable is } \\
\text { "lawful money held, national banks, country districts." }\end{array}$ \\
\hline $\begin{array}{l}\text { Stock } \\
\text { Price } \\
\text { Index }\end{array}$ & $\begin{array}{l}\text { NBER Macrohistory database series m11025a. Variable is "Index of } \\
\text { All Common Stock Prices" constructed by the Cowles Commission. }\end{array}$ \\
\hline $\begin{array}{l}\text { High- } \\
\text { Grade } \\
\text { Bond Price } \\
\text { Index }\end{array}$ & $\begin{array}{l}\text { NBER Macrohistory database series m11016. Variable is "Amer- } \\
\text { ican Railroad Bond Prices, High Grade" based on the series of } \\
\text { high-grade railroad bonds used by Macaulay (1938). }\end{array}$ \\
\hline $\begin{array}{l}\text { Risk-free } \\
\text { rate }\end{array}$ & $\begin{array}{l}\text { NBER Macrohistory database series m13016. Variable is "Open } \\
\text { Market Rates of Discount for London, Great Britain." }\end{array}$ \\
\hline $\begin{array}{l}\text { Dollar } \\
\text { Exchange } \\
\text { Rates }\end{array}$ & $\begin{array}{l}\text { Exchange rates are for British pound, French franc, German mark, } \\
\text { Dutch guilder. Source: Commercial and Financial Chronicle, var- } \\
\text { ious issues. Each exchange rate is average of high and low quotes } \\
\text { for exchange on demand by leading banks. All quotes taken at end } \\
\text { of month. Exchange rates expressed as dollars per unit of foreign } \\
\text { currency. }\end{array}$ \\
\hline
\end{tabular}

Short- Variable is average of the high and low quotes for double-name Term U.S. choice 60-90 day commercial paper for the last week of the month. Interest Sources: Financial Review, various years (1868-1889, 1914); StatisRate tics for the United States, 1867-1909 pp. 119-138.

Foreign Interest rates are open market rates of discount for London, Paris,

ShortBerlin, and Amsterdam. For London, the discount rate is for 3-

Term

Interest month bank bills. Source: Economist, various issues. Variables use

Rates average of high and low quotes for the last week of each month.

Real GNP Source: Balke and Gordon (1989).

U.S Price Price index is GNP deflator. Source: Balke and Gordon (1989).

Index

Dividends Dividend and Earnings Indices constructed by Cowles Commission and Earn- at annual frequency. Shiller (2000) constructs monthly series using ings linear interpolation. Source: Goyal and Welch (2008).

Call Loan NBER Macrohistory database series m13001a. Variable is "U.S. Interest Call Money Rates, Mixed Collateral."

Rate

U.K. Stock U.K. stock index is the U.K. capital gain index presented in ApPrice $\quad$ pendix 4 of Campbell, Grossman, Turner (2019).

Index

U.K. Divi- Linear interpolation of the annual dividends reported in Grossman dends (2002). 
Excess returns for stocks and bonds are constructed in the usual way. An alternative stock price index has been constructed by Goetzmann, Ibbotson, Peng (2001). Using this index to compute stock excess returns does not alter any of the major conclusions of this paper. NYCH bank balance sheets predict stock excess returns at relatively short horizon, the predictability is stronger when NYCH bank reserves are closer to the minimum reserve requirement. Predictability from balance sheets in these low-reserve states is retained even after controlling for output growth over the forecast horizon. The only result sensitive to the index used is that stock returns are only predicted by NYCH "bankers' banks" LtD ratio growth. Neither type of NYCH LtD ratio growth is a significant predictor of stock returns when entered simultaneously, but only NYCH "bankers' banks" LtD ratio growth has the correct sign. Results using this alternative stock price index available upon request.

Currency excess returns are computed from the perspective of a U.S. investor borrowing in foreign currency through a foreign country's discount market, converting to dollars, and then lending these dollars in the U.S. money market. At the end of the holding period, the U.S. investor then converts the proceeds of the dollar loan into foreign currency to repay the initial foreign loan. The U.S. money market instrument is double-name choice commercial paper. The dollar return index is constructed as an unweighted geometric average of the dollar's excess return against each currency in a given quarter. This construction is the opposite of what most of the existing empirical intermediary asset pricing literature has used for studying U.S. intermediaries, as mentioned in the main text. However, for the purpose of illustrating the role of liquidity risk in U.S. money markets, it is better to construct dollar returns. This way it is clear in the results that an improvement in liquidity conditions for the NYCH banks (increase in cash growth or decrease in LtD ratio growth) forecasts a decrease in dollar excess returns. Dividend yield and earnings-price ratio constructed as in Goyal and Welch (2008). 


\section{Additional Results}

This section presents five additional sets of results. First, I show that the Granger causality from NYCH Bank liquidity positions to loan quantities extends to loan prices as well in Table A2. I do this using the call loan interest rate for the New York market. Second, I show in Figure A1 that the predictability patterns for excess returns generally carry over when using cumulative real returns as the outcome variable, except for currencies (not shown). Third, I show that predictability is still found using non-overlapping samples of excess returns. For two-quarter excess returns I use every other quarter as my observations, for three-quarter excess returns it is every third quarter, and for four-quarter excess returns I use end-of-year observations (every fourth quarter). Fourth, I show that splitting the sample at a lower level of the reserve-deposit ratio does not generally affect the finding that predictability comes from periods when the NYCH banks were closer to hitting the minimum reserve requirement. Fifth, the set of results shown in Table A3 repeats the exercise of Table 3 but replaces future GNP growth with two dummy variables: one denoting when business cycle peaks occur and the other marking business cycle troughs. Again, controlling for an indicator of future economic conditions does not weaken the predictive power of NYCH bank balance sheets when the banks are near the reserve requirement. 
Table A2: Call Loan Granger Causality Test P-Values

\begin{tabular}{lll}
\hline & Levels & Changes \\
\hline \hline LtD Ratio & 0.001 & 0.000 \\
Cash Reserves & 0.057 & 0.001 \\
\hline
\end{tabular}

Notes: Reported p-values are for null hypothesis each variable does not Granger cause either the call loan interest rate or year-over-year changes in the call loan rate. Monthly vector autoregressions (VARs) include 12 lags and are run separately with either NYCH bank loan-to-deposit ratio year-over-year changes or NYCH bank cash reserve year-over-year percent changes as the second variable in the system. Column "Levels" is for a VAR with the call loan rate in levels; Column "Changes" is for a VAR with year-over-year changes in the call rate. 
Figure A1: Cumulative Real Return Forecasts at Quarterly Horizons

Forecasting Real Stock Returns: Reserve Growth

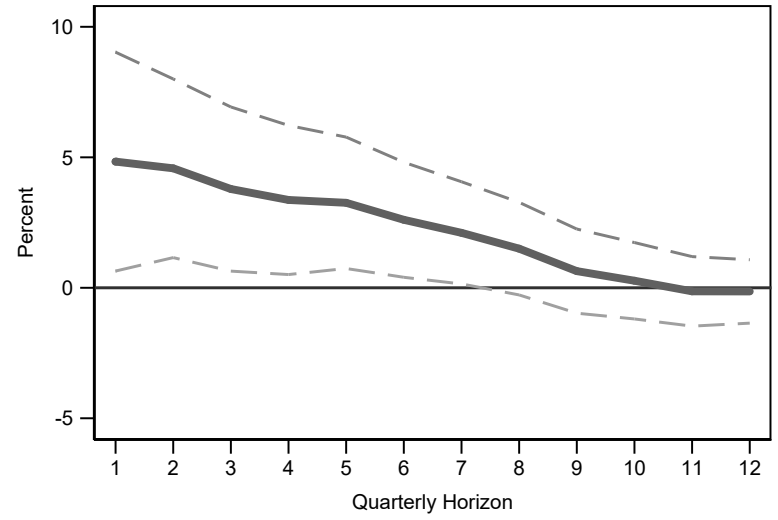

Forecasting Real Bond Returns: Reserve Growth

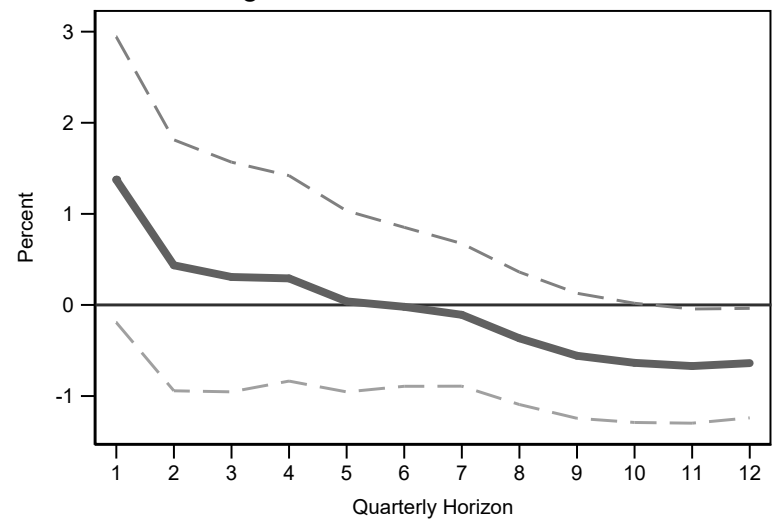

Forecasting Real Stock Returns: Loan-Deposit Ratio Growtr

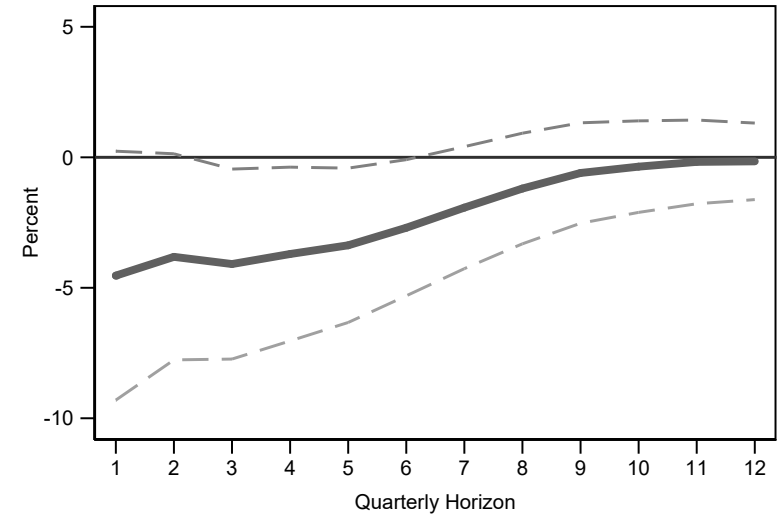

Forecasting Real Bond Returns: Loan-Deposit Ratio Growth

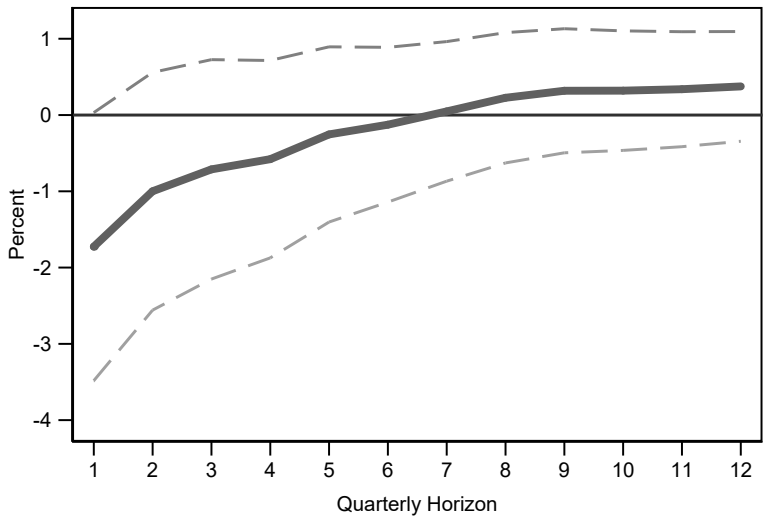

Each panel shows the additional cumulative real return at quarterly horizon $t+h$ for a specific asset class predicted by a standard deviation increase in a given NYCH bank balance sheet variable at time $t$ : year-over-year cash reserve growth or year-over-year loan-to-deposit ratio growth. Estimates are based on equation (1), with controls for year-over-year RGNP growth, one-quarter excess return, dividend yield, and earnings-to-price ratio, all measured at time $t$. Dashed lines are $90 \%$ confidence bands computed using Hodrick (1992) standard errors. 
Figure A2: Excess Return Forecasts with Non-Overlapping Observations
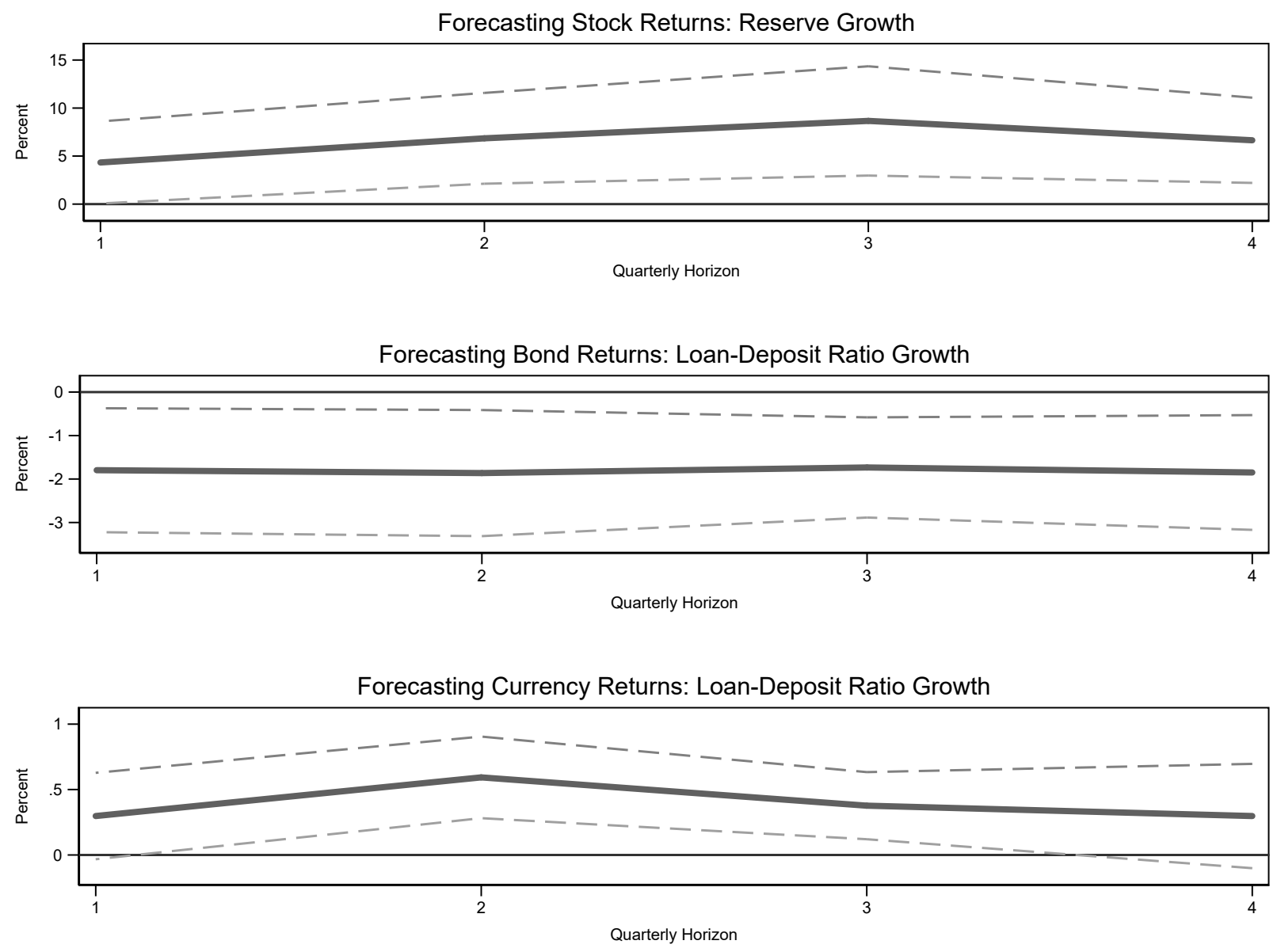

Each panel shows the additional cumulative excess return at quarterly horizon $t+h$ for a specific asset class predicted by a standard deviation increase in a given NYCH bank balance sheet variable at time $t$ : year-over-year cash reserve growth or year-over-year loan-to-deposit ratio growth. Estimates are based on equation (1), with controls for year-over-year RGNP growth, one-quarter excess return, dividend yield, and earnings-to-price ratio, all measured at time $t$. At each horizon, returns come from a sample with no overlapping observations. For two-quarter cumulative excess returns this means returns every other quarter (quarters 1 and 3), for three-quarter cumulative excess returns this means returns every third quarter, and for four-quarter cumulative excess returns this means every fourth quarter (quarter 4 of each year). Dashed lines are $90 \%$ confidence bands computed using robust standard errors. 


\section{Figure A3: Excess Return Forecasts With Low or High Reserve-Deposit Ratio}
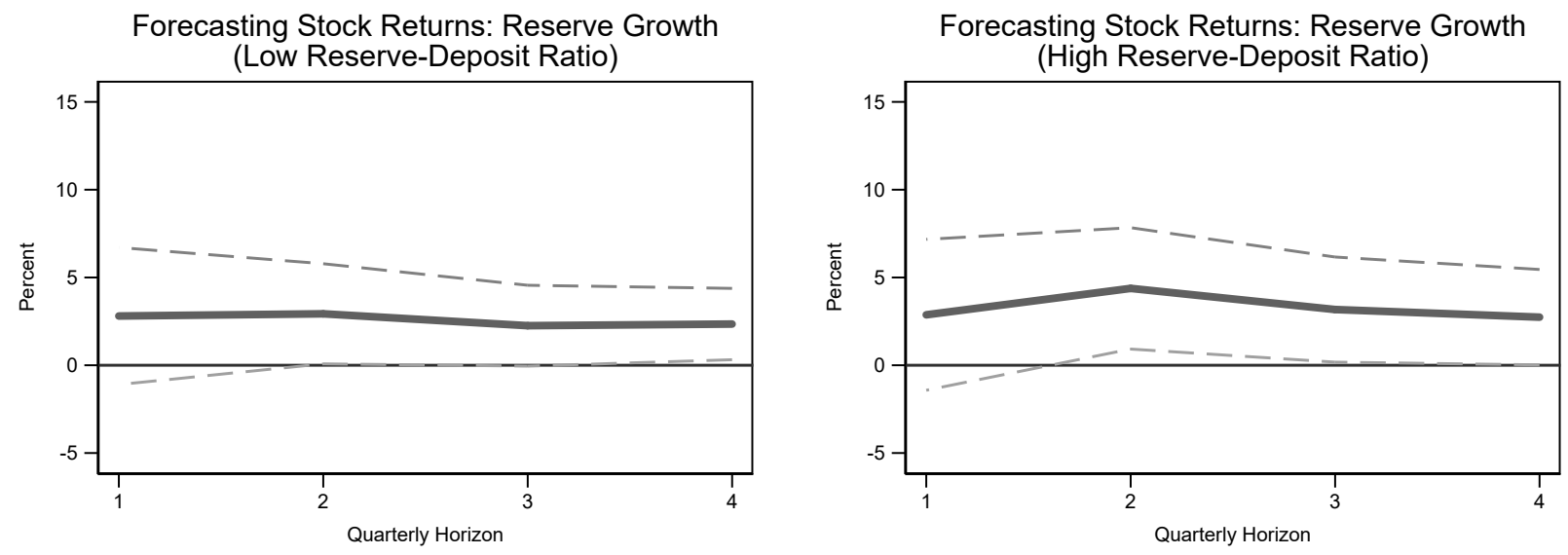

Forecasting Bond Returns: Loan-Deposit Ratio Growth (Low Reserve-Deposit Ratio)

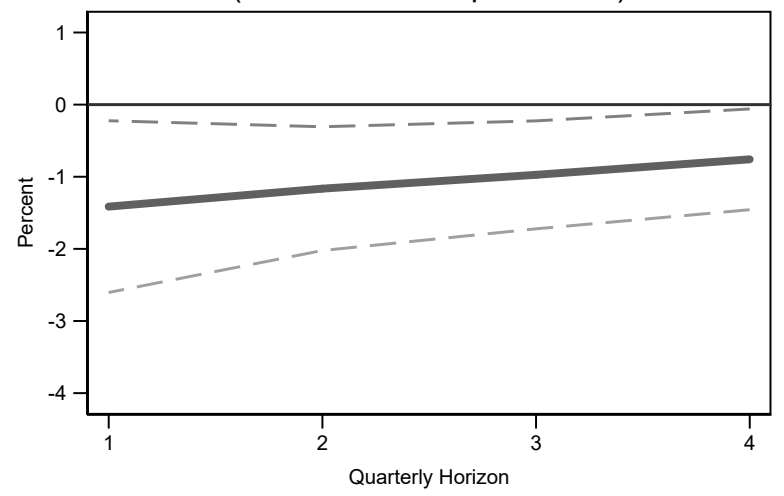

Forecasting Bond Returns: Loan-Deposit Ratio Growth (High Reserve-Deposit Ratio)

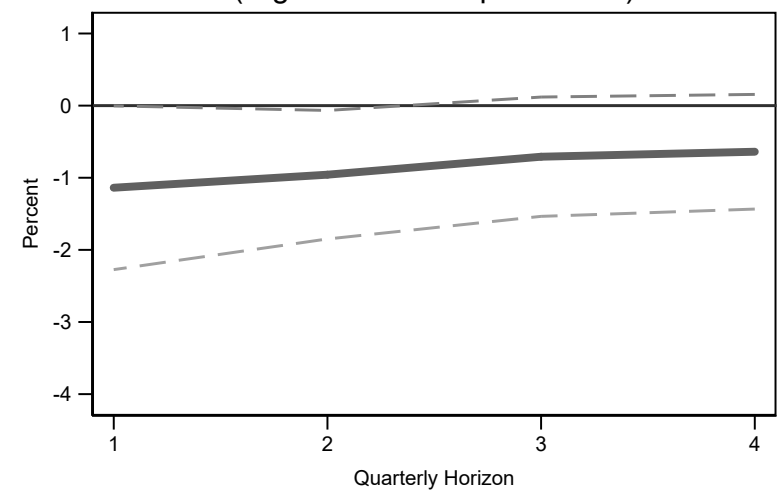

Each panel shows the additional cumulative excess return at quarterly horizon $t+h$ for a specific asset class predicted by a standard deviation increase in a given $\mathrm{NYCH}$ bank balance sheet variable at time $t$ : year-over-year cash reserve growth or year-over-year loan-to-deposit ratio growth. Estimates are based on modified version of equation (1) where each variable is transformed into two versions of itself: a "below" version that is the original value when $\mathrm{NYCH}$ banks' reserve-deposit ratio is in the bottom third of the sample distribution for the estimation period and 0 otherwise and an "above" version that is the original value when NYCH banks' reserve-deposit ratio is in the upper two-thirds of the sample distribution and 0 otherwise. Left panels report predicted additional excess returns for "below" versions of NYCH bank balance sheet variables and right panels report results for "above" versions of NYCH bank balance sheet variables. Dashed lines are 90\% confidence bands computed using Hodrick (1992) standard errors. 
Figure A4: Pound Excess Return Forecasts When Reserve-Deposit Ratio is Below or Above Median
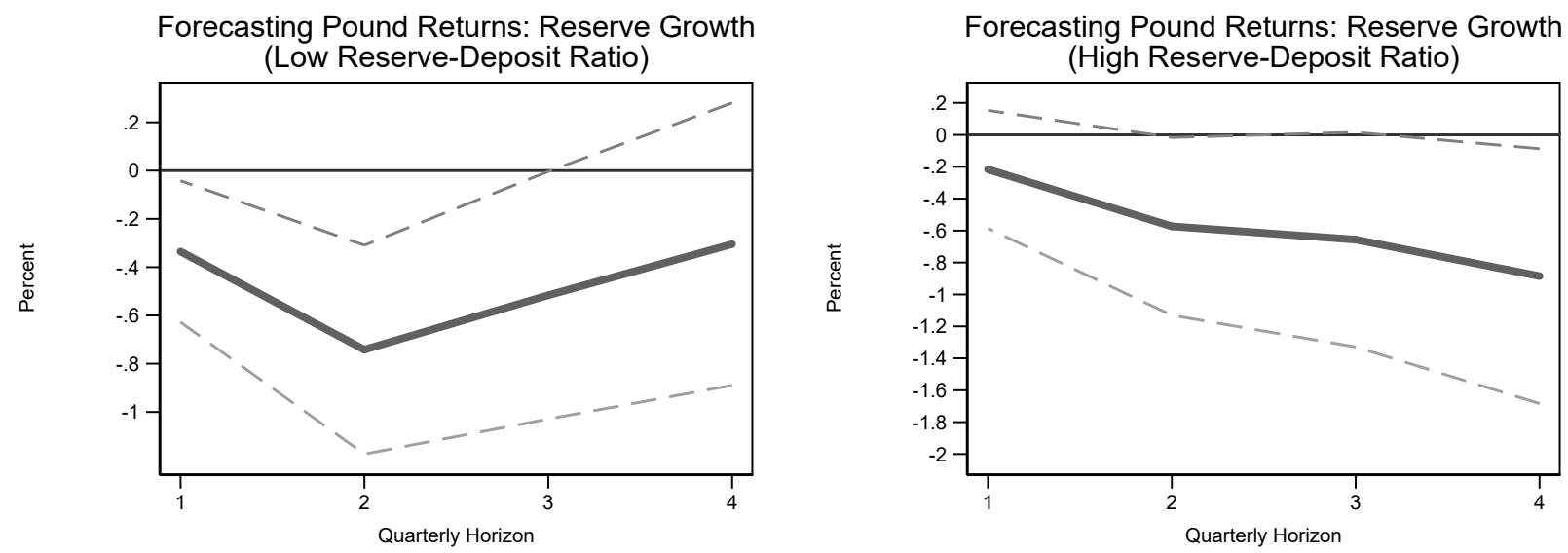

Forecasting Pound Returns: Loan-Deposit Ratio Growtr (Low Reserve-Deposit Ratio)

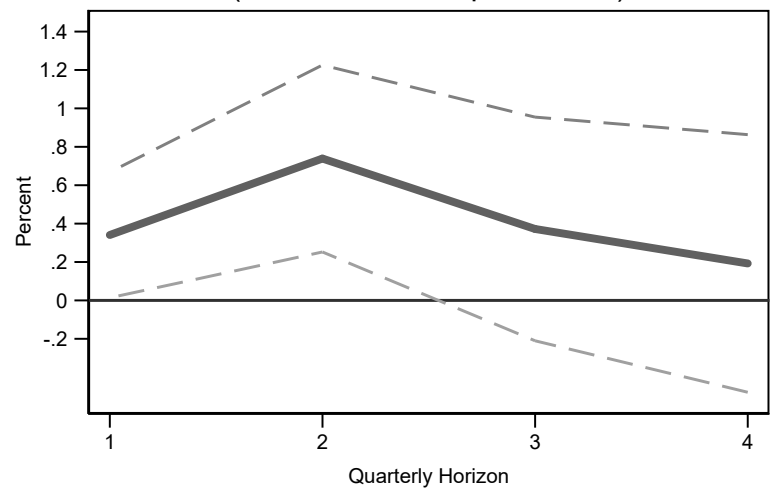

Forecasting Pound Returns: Loan-Deposit Ratio Growth (High Reserve-Deposit Ratio)

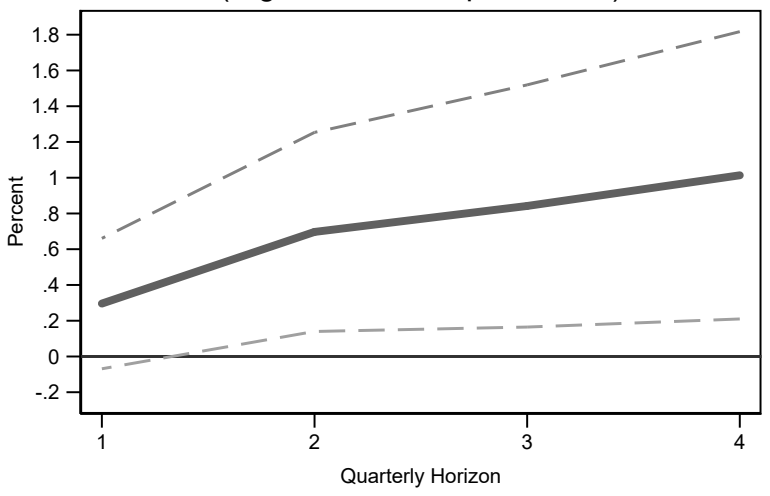

Each panel shows the additional cumulative excess return at quarterly horizon $t+h$ from borrowing in British pounds, lending in U.S. dollars, and converting back to British pounds at the end of the quarter predicted by a standard deviation increase in a NYCH bank balance sheet variable at time $t$. Balance sheet variables are year-over-year growth in either cash reserves or loan-deposit ratio. Estimates are based on a modified version equation (1) where each regressor is transformed into two new versions: a "below" version that is the variable's original value when the NYCH bank reserve-deposit ratio is below its sample median for the estimation period and 0 otherwise and an "above" version that is the variable's original value when the NYCH bank reserve-deposit ratio is above its sample median for the estimation period and 0 otherwise. Left panels show additional predicted excess returns for "below" version of NYCH bank balance sheet variable, while right panels show results for "above" version of NYCH bank balance sheet variable. Dashed lines are 90\% confidence bands computed using Hodrick (1992) standard errors. 
Table A3: Return Predictability with Low Reserves and Business Cycle Turning Points

\begin{tabular}{lllll}
\hline & 1Q-Ahead & 2Q-Ahead & 3Q-Ahead & 4Q-Ahead \\
\hline \hline Stocks (LtD) & $-5.37^{* *}$ & $-5.96^{* * *}$ & $-4.51^{* * *}$ & $-3.85^{* *}$ \\
& $(2.67)$ & $(2.00)$ & $(1.72)$ & $(1.55)$ \\
Stocks (Cash) & $\begin{array}{l}5.19^{* *} \\
(2.34)\end{array}$ & $\begin{array}{l}6.03^{* * *} \\
(1.73)\end{array}$ & $\begin{array}{l}4.53^{* * *} \\
(1.48)\end{array}$ & $\begin{array}{l}3.71^{* * *} \\
(1.33)\end{array}$ \\
& & & & \\
Bonds (LtD) & $-2.51^{* * *}$ & $-1.41^{* * *}$ & $-1.07^{* *}$ & -0.63 \\
& $(0.70)$ & $(0.50)$ & $(0.44)$ & $(0.41)$ \\
Bonds (Cash) & $1.45^{* *}$ & $0.78^{*}$ & 0.61 & 0.23 \\
& $(0.61)$ & $(0.44)$ & $(0.39)$ & $(0.36)$ \\
& & & & \\
Currency (LtD) & 0.29 & $0.37^{* * *}$ & $0.23^{* *}$ & $0.18^{*}$ \\
& $(0.20)$ & $(0.14)$ & $(0.12)$ & $(0.10)$ \\
& & & & -0.11 \\
Currency (Cash) & $-0.30^{*}$ & $-0.33^{* * *}$ & $-0.18^{*}$ & $-0.10)$ \\
& $(0.18)$ & $(0.13)$ & $(0.11)$ & $(0.11)$ \\
\hline
\end{tabular}

Notes: Table reports coefficients for estimates of modified version of equation (1) with two dummies taking a value of 1 if time $t$ is a business cycle peak or trough as additional regressors and each variable transformed into two versions of itself: a "below" version that is the original value when NYCH banks' reserve-deposit ratio is below its sample median and 0 otherwise and an "above" version that is the original value when NYCH banks' reserve-deposit ratio is above its sample median and 0 otherwise. Rows are for different asset class-NYCH balance sheet variable pairs. (LtD) means the NYCH bank balance sheet variable is the yearover-year change in the end-of-quarter loan-to-deposit ratio. (Cash) means the NYCH bank balance sheet variable is the year-over-year percentage growth in end-of-quarter cash reserves. Coefficients show effect of standard deviation increase in "below" version of NYCH bank balance sheet variable. Quarters with business cycle peaks or troughs identified by NBER or Romer (1994). Hodrick (1992) standard errors in parentheses. $* * * \mathrm{p}<0.01,{ }^{*} \mathrm{p}<<0.05,{ }^{*} \mathrm{p}<0.1$. 


\section{The Link Between NYCH Banks and Currency Returns}

I argue in the main text that tightening of liquidity conditions for $\mathrm{NYCH}$ banks forecast higher currency excess returns because of higher liquidity risk premia on U.S. money market instruments. An alternative explanation is that changes in NYCH bank liquidity conditions correlate with changes in depreciation expectations, but the expected depreciation does not materialize. For a substantial portion of the National Banking Era, the U.S. did, in fact, experience a "peso problem" where people expected the dollar to depreciate against most major currencies, but this depreciation never occurred (Hallwood et al., 2000). The possibility of a dollar devaluation was driven by the "Free Silver Movement", a political faction that advocated unlimited coinage of both silver and gold at a mint price ratio that would have resulted in the devaluation of the dollar against gold. The Free Silver Movement never succeeded in enacting their preferred policy, and, by the late 1890s, the movement had effectively died out. Importantly, changes in dollar depreciation expectations due to developments related to the Free Silver Movement affected bank liquidity conditions-including in New York City (Fulford and Schwartzman, 2020; Weiss, 2020).

I test whether unrealized depreciation expectations from silver coinage agitation drive the forecasting relationship between NYCH bank balance sheets and currency returns by running the forecasting regressions only in periods with a lower probability of dollar depreciation. In particular, I exclude all quarters beginning in 1890 and ending in 1896. Fulford and Schwartzman (2020) and Weiss (2020) both present evidence that depreciation expectations were most prominent and volatile during this period. The beginning and end dates correspond to the passage of the Sherman Silver Purchase Act in 1890 and the defeat of the Free Silver candidate William Jennings Bryan in 1896. Both NYCH bank cash reserve growth and LtD ratio growth continue to forecast dollar excess returns even after excluding these dates in a similar manner as in the unrestricted sample. This suggests that the peso problem created by silver coinage agitation is not behind the forecasting ability of $\mathrm{NYCH}$ bank balance sheets for currency excess returns. 


\section{Coefficient Stability and Out-of-Sample Properties}

This section provides evidence on the out-of-sample properties of the predictability of excess returns using NYCH bank balance sheets. This is done to address critiques that a statistically significant predictive relationship may hold in-sample but not out-of-sample simply due to a data-mining bias (Goyal and Welch, 2008). First, I show that coefficients on the NYCH bank balance sheet variables are relatively stable across rolling samples within the estimation period for both stock and bond returns. Next, I compute the out-of-sample $R^{2}$ of Campbell and Thomas (2008) for cumulative stock and bond excess returns from 1 to 4 quarters in the future. I test the statistical significance using the Clark and West (2007) statistic.

Figure A5 shows the relative stability of the coefficients for stock and bond excess returns estimated across different sample periods using two different methods. The left panels show coefficients estimated using rolling 10-year windows beginning in 1880:Q1. The right panels show coefficients estimated with a recursive rolling window starting in 1880:Q1 initially with a size of 10 years. The window then expands by one quarter until reaching 1913:Q4. Across asset classes and sample periods, the coefficients generally retain the expected sign and are statistically significant.

Table A4 shows the Campbell and Thomas (2008) out-of-sample $R^{2}$ for stock and bond excess returns at 1- to 4-quarter horizons. The in-sample period is 1880:Q1 to 1896:Q4, with the out-of-sample period 1897:Q1 to 1913:Q4. The $R^{2}$ compares the mean squared forecast

error (MSFE) for a regression of excess returns on lagged NYCH bank cash reserve growth for stocks or lagged NYCH bank LtD ratio growth for bonds using all data up to date $t$ with the MSFE of an average of historical returns up to date $t$ for all $t$ in the out-of-sample period. In all cases, the out-of-sample $R^{2}$ is positive, meaning $\mathrm{NYCH}$ bank balance sheets provide additional information useful for predicting excess returns. Further, the $R^{2}$ is greater than 10 for both stocks and bonds at every horizon with the exception of stocks at one quarter ahead. Below the $R^{2}$, Table A4 reports the Clark and West (2007) t-statistic in parentheses. In all cases, the out-of-sample $R^{2}$ is statistically significantly different from zero. 
Figure A5: Forecast Coefficients from Rolling Estimations
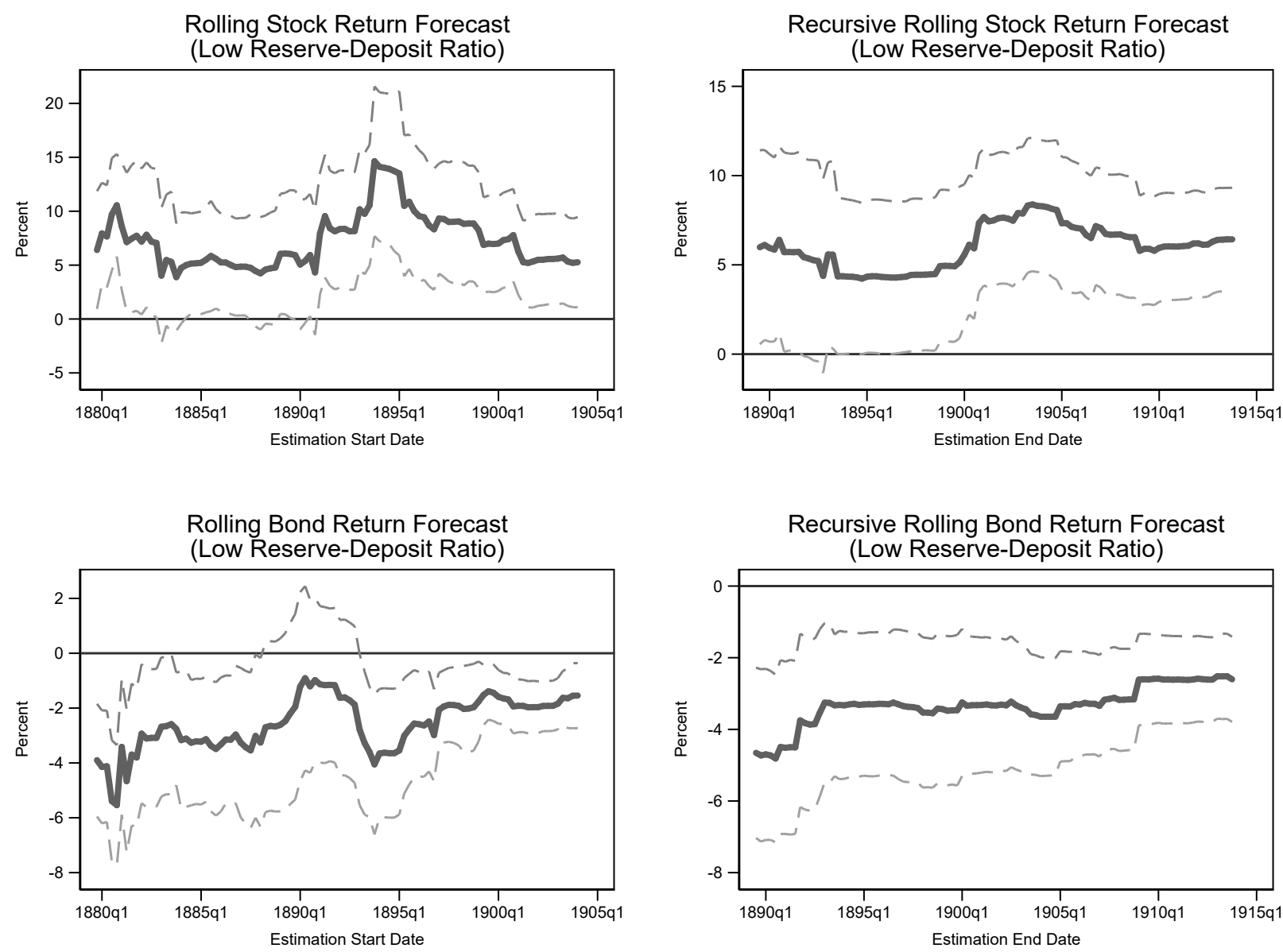

Each panel plots the coefficient for a standard deviation increase in a $\mathrm{NYCH}$ bank balance sheet variable on cumulative excess returns from a set of rolling regressions. In each panel and sample period, the regressions are run using the "below" and "above" versions of the variables that are their actual value when the NYCH banks reserve-deposit ratio is below its sample median (for the "below" variables) and 0 otherwise, or are their actual values when the reserve-deposit ratio is above its sample median and 0 otherwise (for the "above" variables). The upper left panel shows the additional cumulative 2-quarter ahead stock excess returns forecast by a standard deviation increase in year-over-year NYCH bank cash reserve growth ("below" version) over rolling 10-year windows beginning with 1880:Q1. The upper right panel reports coefficients for the additional cumulative 2-quarter ahead stock excess return forecast by a standard deviation increase in year-over-year NYCH bank cash reserve growth ("below" version) over a recursive rolling sample beginning with a 10-year window in 1880:Q1. The bottom left panel shows the additional 1-quarter ahead bond excess returns forecast by a standard deviation increase in year-over-year NYCH bank loan-deposit ratio growth ("below" version) over rolling 10-year windows, beginning with 1880:Q1. The bottom right panel shows the additional 1-quarter ahead bond excess returns forecast by a standard deviation increase in year-over-year $\mathrm{NYCH}$ bank loan-deposit ratio growth ("below" version) over a recursive rolling sample beginning with a 10-year window in 1880:Q1. Left panels are from regressions of excess returns on NYCH bank balance sheet changes only. Regressions for right panels include full set of controls. Dashed lines are 90\% confidence intervals using Hodrick (1992) standard errors. 
Table A4: Out-of-Sample $R^{2}$

\begin{tabular}{lllll}
\hline & 1Q-Ahead & 2Q-Ahead & 3Q-Ahead & 4Q-Ahead \\
\hline \hline Stocks & $5.3^{* *}$ & $11.4^{* * *}$ & $11.8^{* * *}$ & $10.2^{* *}$ \\
& $(2.28)$ & $(2.68)$ & $(3.08)$ & $(2.23)$ \\
\multirow{4}{*}{ Bonds } & & & & \\
& $20.7^{* * *}$ & $23.0^{* * *}$ & $20.8^{* * *}$ & $17.9^{* *}$ \\
& $(3.49)$ & $(3.14)$ & $(2.46)$ & $(1.86)$ \\
\hline
\end{tabular}

Notes: Table reports out-of-sample $R^{2}$ for stocks and bonds based on Campbell and Thompson (2008). The $R^{2}$ compares the MSFE from rolling univariate regressions of excess returns on NYCH bank cash reserve growth for stocks and NYCH bank LtD ratio growth for bonds to the MSFE for rolling historical averages of excess returns. The in-sample period is 1880:Q1 to 1896:Q4, and the out-of-sample period is 1897:Q11913:Q4. The t-statistics for a difference in MSFE based on Clark and West (2007) are reported below in parentheses. ${ }^{* * *} \mathrm{p}<0.01,{ }^{* *} \mathrm{p}<0.05,{ }^{*} \mathrm{p}<0.1$. 


\section{Bankers' Banks and Other NYCH Banks}

Here I discuss in greater detail the similarities and differences between those NYCH banks that funded themselves mainly with bankers' balances and those that did not. Ultimately the primary difference between the "bankers' banks" and the other NYCH banks is the much greater importance of call loans in the bankers' banks portfolio, and therefore the importance of these bankers' banks for the functioning of the call loan market.

Aside from the obvious funding difference (though bankers' balances were based on deposits from individuals in banks outside of New York City), bankers' banks and the other banks of the NYCH differed in the share of their assets invested in call loans. Based on data cited by Myers (1931), the six largest holders of bankers' balances in 1910 held around 80 percent of their loans and discounts as call loans. The other NYCH banks held only about 50 percent of their loan portfolio as call loans. Instead these banks likely invested more heavily in short-term commercial credit, such as discounts of unsecured commercial paper. It is worth emphasizing that even if a smaller portion of the other NYCH banks' assets were invested in overnight loans, their loan portfolio was still very short-term, with most loans having fewer than six months until maturity at issuance.

Despite these significant differences in the composition of their loan portfolios, the behavior of the liquidity measures looks fairly similar between the two types of banks in the NYCH, as shown in Figure A6. For both the reserve-deposit ratio and reserve growth, the correlation between the two types of banks is around 0.7. For LtD ratio growth, the correlation is weaker at 0.3 . The time series of the reserve-deposit ratio for the two types of banks demonstrated what was noted in the main text: both the level of the ratio and the changes in the ratio are similar between the two types of banks. Again, this is important because it suggests that any differences in predictability using the two types of banks' balance sheets should not be coming from differences in how constrained these banks are in expanding their supply of loans. In other words, a finding of no predictability using other $\mathrm{NYCH}$ banks' balance sheets is not an indicator that these banks were simply never constrained 
in expanding their loans. As shown in Figure A7, there is also not predictability when the other NYCH banks were near the minimum reserve requirement.

Figure A6: NYCH Bank Liquidity Measures by Bank Type
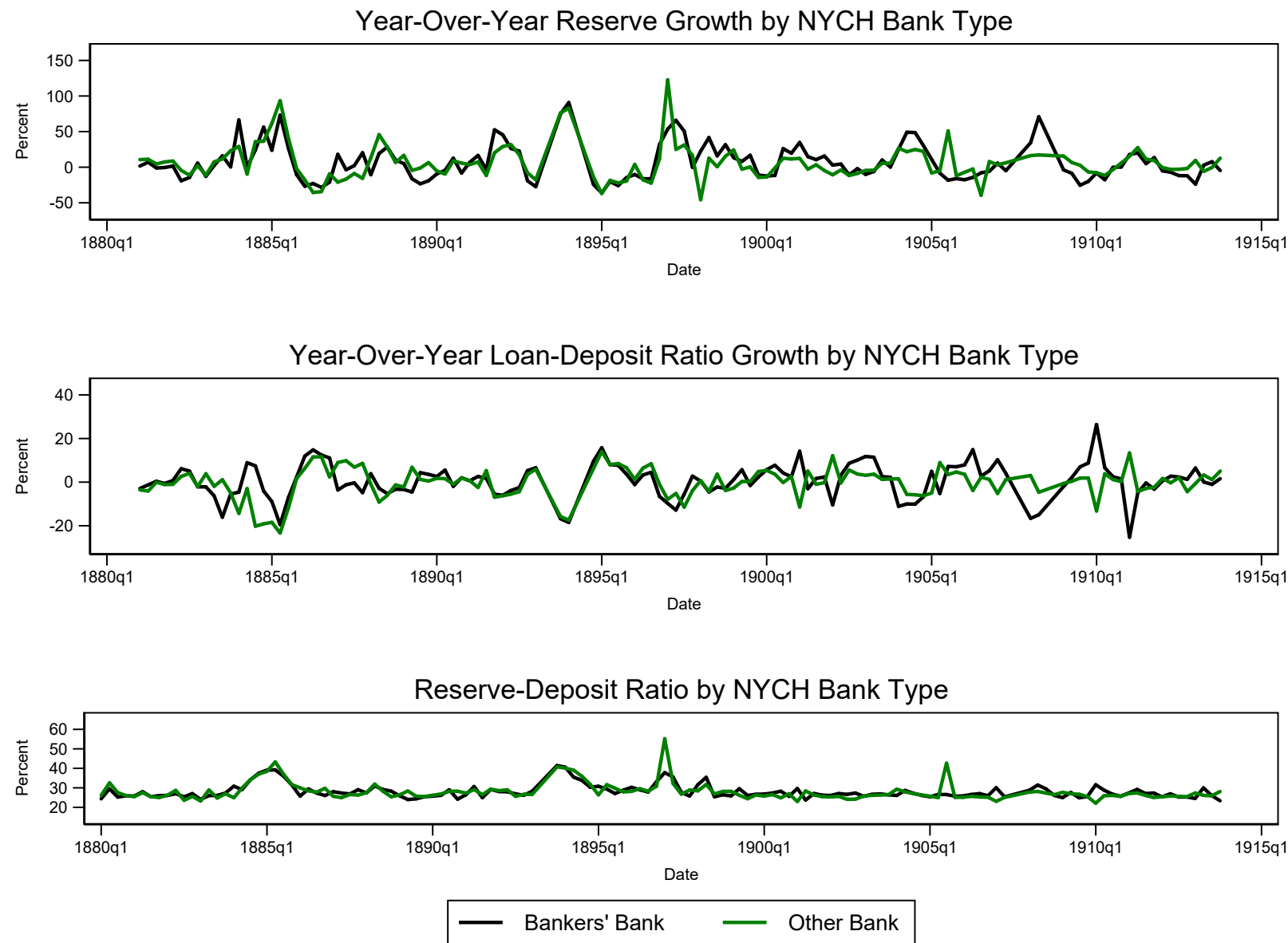

Each panel plots a quarterly liquidity measure for the NYCH banks by bank type. "Bankers' Banks" are the top holders of bankers' balances (deposits from other commercial banks) in each year from 1880-1913. "Other banks" are all other banks in the NYCH. 
Figure A7: Excess Return Forecasts using Other NYCH Bank Balance Sheets

Forecasting Stock Returns: Other Bank Loan-Deposit Ratio Growth: Below

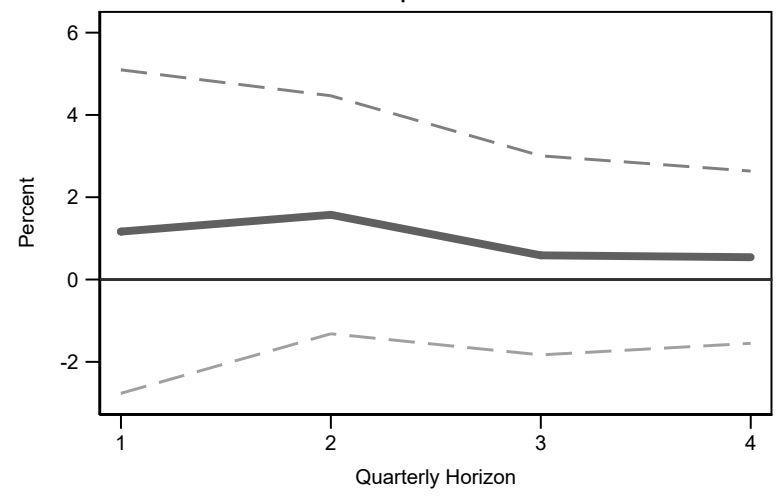

Forecasting Bond Returns: Other Bank Loan-Deposit Ratio Growth: Below

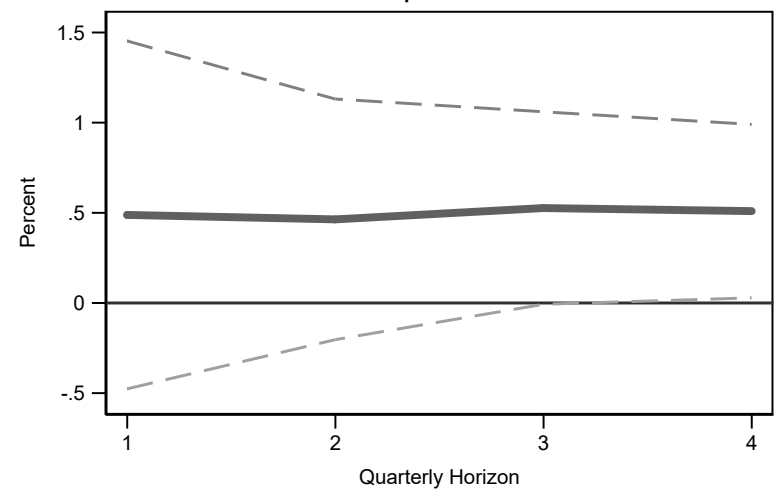

Forecasting Stock Returns: Other Bank Loan-Deposit Ratio Growth: Above

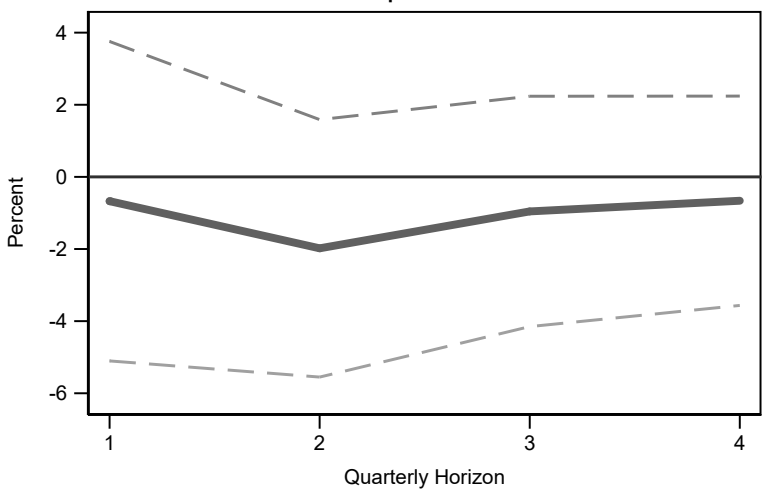

Forecasting Bond Returns: Other Bank Loan-Deposit Ratio Growth: Above

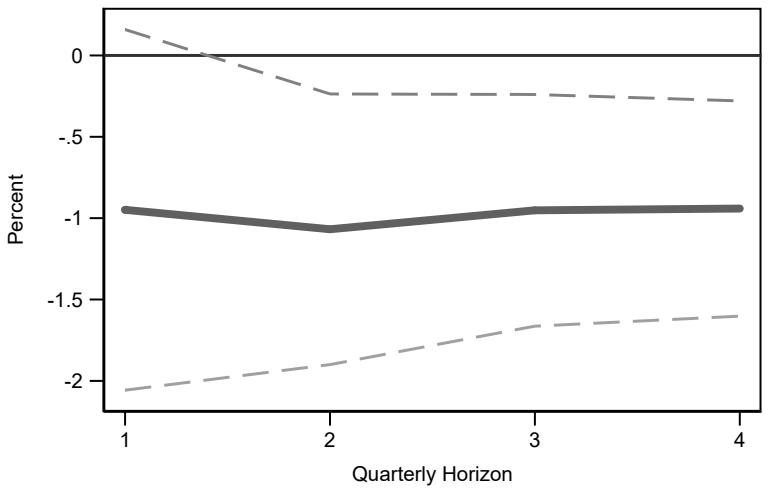

Each panel shows the additional cumulative excess return at quarterly horizon $t+h$ for a specific asset class predicted by a standard deviation increase in "other" NYCH bank year-over-year loan-to-deposit ratio growth at time $t$. Estimates are based on a modified version of equation (1) where $\mathrm{NYCH}$ bank loan-to-deposit ratio growth is computed using only the other (non- "bankers' banks") NYCH banks and where each original regressor is transformed into two new variables: one that is the original value when other NYCH banks' reserve-deposit ratio is below its sample median and 0 otherwise and another that is the original value when other $\mathrm{NYCH}$ banks' reserve-deposit ratio is above its sample median and 0 otherwise. Left panels report the predicted additional excess returns using the "below" versions of other NYCH bank loan-to-deposit ratio growth, and right panels report results for "above" versions of other NYCH bank loan-to-deposit ratio growth. Dashed lines are 90\% confidence bands computed using Hodrick (1992) standard errors. 


\section{Country Banks and Return Predictability}

Generally, because of the structure of the national banking system, country bank behavior affected the balance sheets of the NYCH banks. However, because country banks could hold reserves either in the form of cash or deposits at reserve city banks, changes in country bank cash reserves are not mechanically linked to changes in $\mathrm{NYCH}$ reserves. Indeed, changes in cash holdings of country banks are only weakly correlated with the changes in cash reserves for the NYCH banks. Additionally, in a quarterly vector autoregression, lagged values of country banks' cash reserve growth are negatively correlated with their loan growth, and, in a vector autoregression with one lag, country bank cash growth Granger causes loan growth, with the null hypothesis of no Granger causality is rejected at the five percent level of statistical significance.

Country bank cash reserve growth is not a useful predictor for asset prices, as seen in Table A5. For both stocks and bonds, and over the same horizons that NYCH bank reserve growth predict excess returns, cash reserve growth for country banks is not related to excess returns in a statistically significant way. Further, given that country banks' cash reserve growth is a predictor of their loan growth, this suggests that country bank loan growth does not directly affect asset prices. This undermines the argument that growth in bank credit conditions more generally are what matter for asset prices. Instead, it is the NYCH banks that are important for asset returns. 
Table A5: Forecasts Using Country Bank Cash Reserve Growth

\begin{tabular}{lllllll}
\hline & 1Q-Ahead & 2Q-Ahead & 3Q-Ahead & 4Q-Ahead & 5Q-Ahead & 6Q-Ahead \\
\hline \hline Stocks & 0.19 & -0.03 & -0.50 & -0.63 & -0.30 & -0.34 \\
& $(3.15)$ & $(2.67)$ & $(2.49)$ & $(2.23)$ & $(1.99)$ & $(1.82)$ \\
\multirow{3}{*}{ Bonds } & 1.10 & 0.30 & 0.31 & 0.27 & 0.10 & -0.02 \\
& $(0.86)$ & $(0.68)$ & $(0.61)$ & $(0.57)$ & $(0.53)$ & $(0.51)$ \\
\hline
\end{tabular}

Notes: This table reports coefficients for predictive regressions based on estimating equation (1), replacing the NYCH bank balance sheet variable with the year-over-year percent growth in quarterly country bank cash reserves. All other predictor variables remain the same. Coefficients are reported for a standard deviation increase in country bank cash reserve growth. Hodrick (1992) standard errors in parentheses. ***p<0.01, ${ }^{* *} \mathrm{p}<0.05,{ }^{*} \mathrm{p}<0.1$. 


\section{Additional References}

Andrew, A. Piatt. (1906). "The Influence of the Crops Upon Business in America," Quarterly Journal of Economics 20(3): 323-352.

Balke, Nathan S. and Robert J. Gordon. (1989). "The Estimation of Prewar Gross National Product: Methodology and New Evidence," Journal of Political Economy 97(1): 38-92.

Campbell, Gareth, Richard S. Grossman, and John D. Turner. (2019). "Before the Cult of Equity: New Monthly Indices of the British Share Market, 1829-1929," Mimeo.

Campbell, John Y. and Samuel B. Thompson. (2008). "Predicting Excess Returns Out of Sample: Can Anything Beat the Historical Average?" Review of Financial Studies 21(4): 1509-1531.

Chamberlain, Lawrence. (1911). The Principles of Bond Investment. New York: Henry Holt and Company.

Clark, Todd E. and Kenneth D. West. (2007). "Approximately Normal Tests for Equal Predictive Accuracy in Nested Models," Journal of Econometrics 138(1): 291-311.

Fulford, Scott L. and Felipe Schwartzman. (2020). "The Benefits of Commitment to a Currency Peg: Aggregate Lessons from the Regional Effects of the 1896 U.S. Presidential Election," Review of Economics and Statistics 102(3): 600-616.

Grossman, Richard S. (2002). "New Indices of British Equity Prices, 1870-1913," Journal of Economic History 62(1): 121-146.

Hall, Henry. (1909). How Money Is Made in Security Investments. New York: The De Vinne Press.

Hallwood, C. Paul, Ronald Macdonald, and Ian W. Marsh. (2000). "Realignment Expectations and the U.S. Dollar 1890-1897: Was there a 'Peso Problem'?" Journal of Monetary Economics 46: 605-620.

Hollander, Jacob H. (1911). Bank Loans and Stock Exchange Speculation. Washington, D.C.: Government Printing Office.

Pratt, Sereno S. (1912). The Work of Wall Street. New York: D. Appleton and Company.

Selden, George C. (1917). The Machinery of Wall Street. New York: Magazine of Wall Street.

Shiller, Robert. (2000). Irrational Exuberance. Princeton: Princeton University Press.

Weiss, Colin R. (2020). "Contractionary Devaluation Risk: Evidence from the Free Silver Movement, 1878-1900," Review of Economics and Statistics Forthcoming. 